\title{
REVIEW
}

\section{The key role of nitric oxide in hypoxia: \\ hypoxic vasodilation and energy supply-demand matching}

\author{
Michele Umbrello ${ }^{1,2}$; Alex Dyson ${ }^{1}$; Martin Feelisch ${ }^{3}$; Mervyn Singer ${ }^{1}$ \\ From: ${ }^{1}$ Bloomsbury Institute of Intensive Care Medicine, Dept of Medicine, University College London, \\ London, UK (MU, AD, MS), 'Dipartimento di Fisiopatologia Medico-Chirurgica e dei Trapianti, \\ Università degli Studi di Milano, Milano, Italy (MU), and ${ }^{3}$ University of Southampton School of \\ Medicine, Southampton General Hospital, Tremona Road, Southampton, UK (MF)
}

Running head: Nitric Oxide and energy balance in hypoxia

\section{Corresponding author:}

Prof Mervyn Singer, MD FRCP

Bloomsbury Institute of Intensive Care Medicine, University College London, Cruciform Building, Gower Street, London WC1E 6BT, United Kingdom

email: m.singer@ucl.ac.uk

Word count: abstract: 249; text: 8836; reference number: 251; greyscale illustrations: 7 


\section{Abstract}

SIGNIFICANCE: A mismatch between energy supply and demand induces tissue hypoxia with the potential to cause cell death and organ failure. Whenever arterial oxygen concentration is reduced, increases in blood flow - 'hypoxic vasodilation' - occur in an attempt to restore oxygen supply. Nitric oxide is a major signalling and effector molecule mediating the body's response to hypoxia, given its unique characteristics of vasodilation (improving blood flow and oxygen supply) and modulation of energetic metabolism (reducing oxygen consumption and promoting utilization of alternative pathways).

RECENT ADVANCES: This review covers the role of oxygen in metabolism and responses to hypoxia, the hemodynamic and metabolic effects of nitric oxide, and mechanisms underlying the involvement of nitric oxide in hypoxic vasodilation. Recent insights into nitric oxide metabolism will be discussed, including the role for dietary intake of nitrate, endogenous nitrite reductases, and release of nitric oxide from storage pools. The processes through which nitric oxide levels are elevated during hypoxia are presented, namely (i) increased synthesis from nitric oxide synthases, increased reduction of nitrite to nitric oxide by heme- or pterin-based enzymes and increased release from nitric oxide stores, and (ii) reduced deactivation by mitochondrial cytochrome c oxidase.

CRITICAL ISSUES: Several reviews covered modulation of energetic metabolism by nitric oxide, while here we highlight the crucial role NO plays in achieving cardiocirculatory homeostasis during acute hypoxia through both vasodilation and metabolic suppression FUTURE DIRECTIONS: We identify a key position for nitric oxide in the body's adaptation to an acute energy supply-demand mismatch.

Keywords: Hypoxic vasodilation; nitric oxide; oxygen supply-demand balance 


\section{Introduction}

Patients undergoing major surgery or suffering critical illness have increased cellular energy demands yet commonly experience challenges in ensuring an adequate oxygen supply. An oxygen supply-demand imbalance can be immediately life-threatening, such as in cardiac arrest or major haemorrhage, or it may cause more insidious damage. As organ function is critically linked to both oxygen availability (30) and adequate utilization, bioenergetic deficiency is likely to be a crucial factor underlying the pathogenesis of cell death (39) and multiple organ failure $(18,202)$.

The main purpose of the cardiovascular system is to provide oxygen and metabolic substrates at a rate that can both meet and respond rapidly to changes in local demand. Whenever arterial oxygen concentration is reduced, increases in local blood flow - 'hypoxic vasodilation' - occur in an attempt to restore oxygen supply (102). The ability of hypoxia to increase tissue blood flow is a local response that can be demonstrated in isolated organs, thus it can occur without the involvement of neurally-mediated reflex mechanisms. A variety of mediators such as adenosine (22), ATP-sensitive potassium channels (65) and prostaglandins (173) are implicated, however significant human and animal data point towards nitric oxide (NO) as a major regulator of vascular perfusion and matching of energy supply and demand $(24,25,76,119,147,190)$. Nevertheless, considerable controversy persists with respect to its sources and mechanisms of action.

Several reviews have covered modulation of energetic metabolism by nitric oxide $(33,219,232)$. In this article we highlight the crucial role NO plays in achieving cardiocirculatory homeostasis during acute hypoxia through both vasodilation and metabolic suppression, and the various mechanisms through which NO production is enhanced. We identify a key position for nitric oxide in the body's adaptation to an acute energy supplydemand mismatch. 


\section{Bioenergetic reactions and the role of oxygen}

Living cells constantly perform work to maintain their structures, synthesize cellular components, generate transmembrane ionic gradients, and to undertake their physiologic roles. As most of these metabolic processes are thermodynamically unfavorable, they are coupled directly or indirectly to the hydrolysis of ATP to provide the necessary free energy. ATP supply is maintained through mitochondrial and cytoplasmic reactions that proceed with and without the need for oxygen (32). With its net yield of 2 moles ATP per mole of glucose, glycolysis is generally insufficient to maintain steady-state energy levels in most cell types. Exceptionally, some cells (e.g. erythrocytes) rely solely upon glycolytic production of ATP. Many immune cells use glucose and glutamine as their primary fuel sources, although ketone bodies and fatty acids can be used to a lesser degree (168). Glucose appears to be particularly necessary for cell survival, size, activation and cytokine production. Resting lymphocytes have low-energy needs and derive most of their ATP from oxidative phosphorylation; switching to the activated state requires a dramatic increase in metabolism, which is mainly derived from rapid upregulation of glycolysis (80). Organs also vary in their predominant energy substrate. Whereas most utilize carbohydrates as their major energy source, some (e.g. cardiomyocytes) predominantly use fatty acids. Notably, this preference can change with a reduction in oxygen availability.

Pathways leading to ATP synthesis have been extensively studied (145). Briefly, the glycolytic end-product pyruvate, and fatty acids enter mitochondria where they are metabolized to acetyl CoA. This enters the tricarboxylic acid (Krebs') cycle whereby oxidation reactions directly produce ATP equivalents and electron donors. Electrons are transported down the respiratory chain, generating a proton gradient across the inner mitochondrial membrane, which serves as the driving force for phosphorylation of ADP to ATP. By comparison with glycolysis, 1 mole of glucose liberates approximately 30 moles of 
ATP. Oxygen is crucially required as the terminal electron acceptor by the last complex of the chain, cytochrome c oxidase ( $\mathrm{CcO}$, complex IV) (44). In the steady state, approximately $90 \%$ of total body $\mathrm{O}_{2}$ consumption occurs within mitochondria (204), and is primarily directed towards oxidative phosphorylation. A constant $\mathrm{O}_{2}$ supply is thus critical for continued cell function and survival. When compromised (e.g. supply reduced and/or demand excessively increased), a state of metabolic crisis ensues (231) with potential activation of cell death pathways.

Oxygen and nutrients required by mammalian cells to support metabolism cannot be directly obtained in sufficient quantity by diffusion alone. From an evolutionary perspective, this limitation was resolved by the development of a cardio-respiratory system whose activity is closely regulated such that, in the steady state, ventilation delivers oxygen to the alveolar capillaries at the same rate of delivery by the vasculature to the tissues, and of consumption by metabolic processes within the tissues (233). The quantity of oxygen delivered to tissues $\left(\mathrm{DO}_{2}\right)$ depends on arterial oxygen content (mainly carried by hemoglobin) and cardiac output. Regulation and distribution of cardiac output is driven by regional $\mathrm{O}_{2}$ consumption $\left(\mathrm{VO}_{2}\right)$ that proceeds at a rate set by tissue metabolic activity. If $\mathrm{DO}_{2}$ is reduced, $\mathrm{VO}_{2}$ is initially maintained by increased $\mathrm{O}_{2}$ extraction. If delivery is reduced further, a critical point is reached below which tissue extraction cannot increase any further, leading to a fall in $\mathrm{VO}_{2}(212)$. Several complementary macro- and microcirculatory mechanisms act to prevent the onset of tissue hypoxia in the face of a reduced $\mathrm{DO}_{2}$. These include a redistribution of blood flow to 'vital' organs, increased recruitment of perfused microvessels to facilitate $\mathrm{O}_{2}$ availability (233), as depicted in figure 1 and, as discussed later, a decrease in tissue utilization (metabolism)

\section{Sensing hypoxia}

How eukaryotic cells sense reductions in $\mathrm{pO}_{2}$ remains contentious. Five main mechanisms have been proposed (132) based on, respectively, heme-based proteins, $\mathrm{O}_{2}$-sensitive ion 
channels, AMP kinase, NADPH oxidase and mitochondria. Thus, hypoxia may be detected by an allosteric shift towards a deoxy- configuration in proteins capable of reversibly binding $\mathrm{O}_{2}$ at a heme site, or by ion channels affected by local $\mathrm{pO}_{2}$, as has been shown in carotid body cells where hypoxia can inhibit a specific $\mathrm{K}^{+}$current. Reduced $\mathrm{O}_{2}$ levels increase the AMP:ATP ratio thus, at sufficient magnitude, AMP-activated protein kinases (AMPK) are induced, modulating cellular metabolism at various levels via target protein phosphorylation. With molecular $\mathrm{O}_{2}, \mathrm{NADPH}$ oxidase or other non-mitochondrial enzymes such as xanthine oxidase or flavin-containing dehydrogenases generate superoxide $\left(\mathrm{O}_{2}{ }^{-}\right)$, providing a second messenger that may regulate cellular activity through redox modifications. Finally, increased mitochondrial reactive oxygen species (ROS) production during hypoxia may result in mitochondrial $\mathrm{O}_{2}$ sensing through changes in redox state of the electron transport chain, though without necessarily affecting respiration $(50,72,96)$. Mitochondria may play a critical role in oxygen sensing. This model has been controversial as previous studies, which mainly relied on pharmacologic tools, produced conflicting reports (223). However, recent studies using genetic and biochemical approaches have provided evidence for a role of mitochondrial reactive oxygen species (mROS) in oxygen sensing and hypoxia-inducible transcription factor-1 (HIF-1 $\alpha$ ) activation (38). Indeed, blocking superoxide anion production by suppressing the Rieske iron-sulfur protein of complex III impairs HIF-1 $\alpha$ induction by hypoxia, whereas hydrogen peroxide or agents that produce ROS activate HIF-1 $\alpha$ during normoxia (95). These data indicate that mitochondria can function as $\mathrm{O}_{2}$ sensors and stabilize HIF-1 $\alpha$ during hypoxia by releasing ROS to the cytosol (96).

The hypoxia-inducible transcription factor 1 (HIF-1) pathway is central to the body's innate response to the stressful condition of hypoxia. HIF is a heterodimer composed of $\alpha$ and $\beta$ subunits that induces expression of multiple genes that promote adaptation and survival (214). The $\beta$ subunit is constitutively expressed, while $\alpha$ subunit expression is tightly regulated by the local oxygen tension through the action of prolyl hydroxylase (PHD). When $\mathrm{O}_{2}$ tension falls below a critical threshold, proline residues cannot be hydroxylated. This 
prevents ubiquitination, allowing the $\alpha$-subunit to accumulate and hetero-dimerize with HIF$1 \beta$. The heterodimer can then bind to specific DNA regions within the nucleus, exerting its regulatory activities. The PHDs are considered effective $\mathrm{O}_{2}$ sensors in their own right as their $\mathrm{Km}$ values for oxygen are above atmospheric $\mathrm{O}_{2}$ concentrations (110). This allows small changes in $\mathrm{O}_{2}$ supply to affect the enzyme's activity.

For responses to occur, a decrease in $\mathrm{PO}_{2}$ must be detected by an $\mathrm{O}_{2}$ sensor that activates signalling pathways triggering functional responses. In general, adaptation to acute changes in $\mathrm{O}_{2}$ concentration (lasting from seconds to minutes) principally occur as a result of alterations of pre-existing proteins (e.g. involving phosphorylation or changes in redox state), whereas chronic changes (lasting from minutes to hours or longer) mainly occur through altered gene expression.

\section{Responding to hypoxia}

\section{(a) Transcriptomic}

Given oxygen's essential role in cellular metabolism, a wide array of responses has evolved to cope with situations of oxygen supply-demand mismatch. Functional adaptation occurs at systemic, tissue and cellular levels, ultimately leading to a new phenotype that enhances the likelihood of survival (211). Such adaptation depends both on the modulation of activity of various enzymatic systems by metabolic messengers (e.g. pH, phosphate potential, redox potential), and on altered gene transcription with increased expression of genes encoding, for example, growth factors (e.g. VEGF, PDGF- $\beta$ ), cytokines (e.g. IL-1, IL-8), endothelin and adhesion molecules (e.g. VCAM-1, ICAM-1).

The AMP kinase (AMPK) system is a well-conserved pathway for maintaining the balance between energy production and utilization (103). Triggered by an increase in AMP:ATP ratio, this system switches on an energy-preserving phenotype, both rapidly through 
phosphorylating metabolic enzymes, and by a longer-term adaptation through regulating gene expression via phosphorylation of transcription factors and co-activators. AMPK targets include carbohydrate homeostasis, lipid metabolism, protein synthesis, mitochondrial biogenesis, cell signalling, proliferation, gene expression and transmembrane ion transport (128).

Responses to hypoxia that involve induction or repression of gene expression are mainly mediated by HIF-1 (214). Three isoforms of HIF $\alpha$ have been characterized, of which HIF-1 $\alpha$ and HIF-2 $\alpha$ are the most structurally similar and best studied. HIF-3 $\alpha$ can be found as multiple splice variants, some of which can even inhibit activity of HIF-1 $\alpha$ and HIF-2 $\alpha$ (169). While HIF- $1 \alpha$ is expressed ubiquitously in all cells, the other isoforms are only selectively expressed in certain tissues, such as vascular endothelium, lungs and kidney. Activation of HIF-1 and HIF-2 can regulate expression of many other genes induced by hypoxia, such as vascular endothelial growth factor (VEGF), a potent angiogenic factor that contributes to long-term adaptation to hypoxia through new blood vessel formation (130). However, each HIF isoform may have their unique targets offering different adaptive pathways to hypoxia (160); HIF-1 preferentially induces genes coding for the glycolytic pathway whereas HIF-2 is involved in regulation of genes important for cell cycle progression and induction of erythropoietin (161). The two HIF isoforms also have distinct and somewhat opposing roles to NO regulation in macrophages. While HIF-1 promotes iNOS expression and increases NO production, HIF-2 promotes arginase expression, reducing the amount of arginine available for NO synthesis (229). This may offer a balancing regulatory mechanism for NO homeostasis.

Apart from $\mathrm{O}_{2}$ tension many other factors govern $\mathrm{HIF} \alpha$ stability, including microRNAs and post-translational modifications such as acetylation (91). In addition to $\mathrm{O}_{2}, \mathrm{PHDs}$ require $\mathrm{Fe}^{2+}, 2$-oxoglutarate and ascorbate to exert their activity, but may be inhibited by NO, Krebs' 
cycle intermediates and reactive oxygen species (126). To date, $>200 \mathrm{HIF}$ gene targets have been identified, including those encoding for proteins involved in angiogenesis, energy metabolism, erythropoiesis, cell proliferation and viability, vascular remodelling, and vasomotor responses (214).

MicroRNAs, specific small, non-coding RNA sequences, also appear to be involved in the hypoxic response (140). These 19- to 24-ribonucleotide sequences, once transferred to the cytoplasm, inhibit target gene expression by translational repression and/or mRNA degradation. A common characteristic of the different microRNAs involved in hypoxic signalling is their dependence upon HIF (141). HIF may thus be the main modulator of the hypoxic response, either through direct gene induction, or by indirect microRNA-mediated gene repression (140). On the other hand, microRNAs may act as positive and negative feedback regulators of HIF-mediated responses (106). miR-210 is consistently upregulated in hypoxia and may play a central role in hypoxic signalling by modulating factors implicated in various pathways, e.g. downregulating expression of different components of the mitochondrial electron transport chain and the Krebs' cycle, interfering with membrane trafficking, modulating migration and adhesion, differentiation and cell cycle (67).

\section{b) Hemodynamic effects}

At the systemic level, adaptation to hypoxemia affects many systems although the most evident changes involve the cardiocirculatory system. This response is composed of essentially unopposed local vasodilation in the heart and brain, and of a balance between the competing effects of locally-induced vasodilation and reflex chemoreceptor-sensed, sympathetic-mediated vasoconstriction in other tissues, e.g. kidney and skeletal muscle (206). This response pattern attempts to maintain an adequate $\mathrm{O}_{2}$ supply-demand ratio, compensating for any reduction in arterial $\mathrm{O}_{2}$ content, while preserving arterial perfusion pressure. Over 130 years ago, Roy and Brown recognized that interrupting tissue perfusion 
produced a local, non neurally-mediated increase in blood flow, and that blood vessels could vary their diameter independently in response to local metabolic needs (208). Indeed, the main hemodynamic effect of hypoxia is systemic vasodilation with increases in cardiac output and heart rate, and redistribution of regional perfusion with increased coronary, carotid and hepatic and decreased renal blood flow. The sympathetic nervous system is activated with increased catecholamine levels but a reduced response to exogenous vasopressors $(55,98,104,156,194,206,207)$. Increases in forearm blood flow, a reduced vasomotor reflex and a reduced response to exogenous norepinephrine and angiotensin were noted in healthy volunteers made hypoxemic (104).

\section{c) Respiratory}

Haldane noted how hypoxia induced a rapid, shallow type of breathing in humans (101). The predominant ventilatory response is an increase in respiratory rate with a rise in bronchiolar tone (127), a response mainly mediated via hypoxemia-responsive peripheral chemoreceptors in the carotid and aortic bodies.

\section{d) Renal and endocrine}

Hypoxemia redistributes blood flow away from the kidney which, in response, increases blood volume via an antidiuretic and sodium-sparing effect $(20,183)$. In volunteers breathing $10.5 \% \mathrm{O}_{2}$, blood pressure fell by $10 \%$ and urine output by $30 \%(109)$, yet vasopressin and cortisol levels significantly increased while urine osmolality more than doubled.

\section{e) Metabolic}

Mammalian cells undergo multiple adaptive modifications of metabolism in response to changes in $\mathrm{O}_{2}$ availability $(184,215)$. Some organs with high metabolic demand (e.g. muscle, liver, brain, heart) cope with the initial energy imbalance through glycogenolysis, 
phosphocreatine dephosphorylation and the adenylate kinase reaction (4). Moreover, a switch in fuel selection from lipid to carbohydrate oxidation optimizes the rate of ATP production by taking advantage of the higher ATP yield per mole of $\mathrm{O}_{2}$ consumed $(94,113)$.

ATP produced from fatty acid oxidation is strictly dependent upon the presence of oxygen. In contrast, glucose-derived ATP originates both from oxygen-dependent glycolysis and on glucose oxidation. During hypoxia, both fatty acid and glucose oxidation decrease, thereby increasing the importance of glycolytic-derived ATP which, in most cell types, only plays a minor role in normoxic conditions (182). However, in order to regenerate $\mathrm{NAD}^{+}$, pyruvate produced from glycolysis is converted to lactate rather than being utilized within the mitochondria, a process that ultimately depends on the presence of $\mathrm{O}_{2}$ as the terminal electron acceptor. Moreover, hydrogen ions. generated by the hydrolysis of glycolyticderived ATP, accumulate as these are not taken up by the mitochondria, and will eventually result in a fall in intracellular $\mathrm{pH}(210)$. Hypoxia, besides causing a critical reduction of oxygen availability for oxidative phosphorylation, also affects other mitochondrial processes including a decrease in Complex I-dependent respiration, and reversal of the direction of operation of the $F_{0} F_{1}$-ATPase (Complex V). This latter effect converts mitochondria into major ATP consumers as they attempt to restore and maintain membrane potential to prevent increased mitochondrial permeability transition and cell death (68).

During hypoxia, expression and activity of carbohydrate transporters, and of enzymes involved in glycogenolysis and glycolysis are increased (215), while pyruvate dehydrogenase activity is inhibited (188). The net effect is a shunting of pyruvate away from mitochondria and an increase in glucose availability and glycolytic flux - the 'Pasteur effect'. Hypoxia also realigns the subunit composition of cytochrome c oxidase $(\mathrm{CcO})$, improving the efficiency of respiration (82). Furthermore, accumulation of the glycolytic intermediate, fructose 1,6-biphosphate, directly inhibits mitochondrial respiration (69), again linking an increase in glycolytic flux to decreases in $\mathrm{O}_{2}$ consumption. 
Further adaptation to hypoxia is achieved through metabolic suppression, measured as a decrease in mitochondrial $\mathrm{O}_{2}$ consumption during hypoxia. This oxygen conformance (111) is recognized, at least to some extent, in human heart and in hepatocytes. It begins at partial pressures of $\mathrm{O}_{2}$ above the critical level at which diffusion limitation into the mitochondria affects oxidative phosphorylation (31). In addition, a reallocation of cellular energy between essential and non-essential ATP-demanding processes provides further defense against the energy mismatch. ATP-consuming processes are arranged in a hierarchy, with processes less critical for cell survival being first sacrificed (30). This is mainly achieved at the level of the two principal ATP consumers: ion pumps and protein synthesis. Hypoxia reversibly suppresses $\mathrm{Na}^{+} / \mathrm{K}^{+}$ATPase activity and inhibits mRNA translation through multiple mechanisms (244). Indeed, a modified phenotype for adaptive hypoxia tolerance is expressed in indigenous highlander human populations (Quechuas, Sherpas and Tibetans), whereby improved coupling between ATP demand and supply pathways protects against imbalances due to environmental $\mathrm{O}_{2}$ limitation (112). Similarly, NO was increased in lowlanders acclimatizing to altitude; this was associated with changes in microcirculatory blood flow which increased local tissue oxygen delivery, in agreement with an adaptative role in hypoxia (147).

\section{Nitric oxide synthesis and metabolism}

\section{a) Production by nitric oxide synthases}

A large proportion of NO synthesis occurs through the L-arginine-NO pathway (177), one of the main metabolic pathways for arginine (246) (as depicted in figure 2). With these reactions, the semi-essential amino acid L-arginine is metabolized to $\mathrm{NO}$ and L-citrulline by a family of nitric oxide synthases (NOS) (135). These enzymes are dimers formed by two monomers consisting of a flavin-containing reductase domain and a heme-containing 
oxygenase domain. The NO synthesis reaction requires the presence of two oxygen molecules plus NADPH, flavin adenine dinucleotide (FAD), flavin mononucleotide (FMN) and tetrahydrobiopterin as coenzymes/cofactors (29). NOS may be 'uncoupled' in the absence (or reduced availability) of either L-arginine or tetrahydrobiopterin, or in the presence of the endogenous NOS inhibitor, asymmetric dimethylarginine (ADMA) $(227,239)$. Here, electrons flowing from the reductase to the oxygenase domain are diverted to molecular $\mathrm{O}_{2}$ rather than to L-arginine, eventually resulting in production of superoxide rather than $\mathrm{NO}(239,247)$. Three isoforms of NOS have been characterized (135). The endothelial (eNOS) and neuronal (nNOS) isoforms are constitutively expressed. Although initially isolated in vascular endothelium and the nervous system, they have since been found in skeletal muscle, lung and liver and, recently, an eNOS-like NO producing machinery has been described in erythrocytes (134). These constitutive isoforms can rapidly increase NO production. In health, they play important regulatory roles in neurotransmission and the cardiovascular system. Production of the inducible isoform (iNOS) depends on transcription; several hours are needed to reach peak activity. Its gene transcript increases on exposure to proinflammatory cytokines and bacterial products. In general, iNOS generates larger (nanomolar vs picomolar) quantities of NO compared to its constitutive isoforms (5). This is related to the amount of protein expressed. The existence of a specific mitochondrial variant of NOS (mtNOS) has been claimed $(88,142)$. However, others challenge its existence as no specific mtNOS sequence has yet been found in mitochondrial DNA, nor has any pathway enabling NOS protein transport into these organelles been identified, nor could it be found when specifically sought (142).

This picture is further complicated by the ability of most cells to express multiple isoforms in different compartments. In the heart, for instance, nNOS is expressed within the sarcoplasmic reticulum and its activation increases contractility, whereas eNOS is confined to the caveolae and inhibits $\beta$-adrenoreceptor-mediated increases in contractility (16). Moreover, constitutively expressed NOS can be modulated by post-translational 
modifications and phosphorylation (216) or be induced (135), while iNOS may be constitutively expressed at low levels in some tissues (189).

\section{b) Dietary nitrite/nitrate intake}

Though traditionally considered as inert oxidative end-products, nitrate $\left(\mathrm{NO}_{3}{ }^{-}\right)$and nitrite $\left(\mathrm{NO}_{2}{ }^{-}\right)$may play an important role in NO homeostasis (164). Diet is a major source of $\mathrm{NO}_{3}{ }^{-}$ with particularly high levels in leafy green vegetables. An average serving of beetroot contains more nitrate than is endogenously generated per day from NO generated by all three NOS isoforms combined. Once absorbed, most nitrate is ultimately excreted in urine. However, up to $25 \%$ is taken up by salivary glands and concentrated in the saliva where it reaches levels 10 -fold higher than in plasma. Facultative anerobe bacteria within the oral cavity then reduce it to nitrite while using it as an alternative electron acceptor to $\mathrm{O}_{2}$ during respiration (165). Nitrite-rich saliva is then swallowed where, within the acidic milieu of the gastric lumen, $\mathrm{NO}_{2}{ }^{-}$is rapidly protonated to nitrous acid that further decomposes to NO. This is termed the "nitrate-nitrite-nitric oxide pathway" (166) (figure 3).

Orally administered nitrate or nitrite can modulate the endogenous NO system in various physiologic and pathophysiologic conditions $(41,241,249)$. Significant increases in plasma $\mathrm{NO}_{3}{ }^{-}$and $\mathrm{NO}_{2}{ }^{-}$levels were measured in human volunteers after beetroot juice ingestion, with lowering of arterial BP by about $10 \mathrm{mmHg}$. This was prevented by interrupting the enterosalivary circulation through non-swallowing of saliva (241), or by selective suppression of the oral microflora with an antiseptic mouthwash (193).

\section{c) Generation by other pathways:}

\section{(i) Systemic nitrite reduction}


Endogenously-formed or dietary nitrite in blood and tissues may be recycled to form NO-like bioactive molecules (Figure 3). In a human forearm blood flow study (90), Gladwin et al found that of the various plasma NO-related species, only $\mathrm{NO}_{2}^{-}$had a significant arterialvenous gradient, indicating a degree of consumption during circulatory transit, and thus suggestive of possible bioactivity. This gradient markedly increased with exercise and inhibition of regional $\mathrm{NO}$ synthesis, suggesting that $\mathrm{NO}_{2}^{-}$is a plasma carrier of $\mathrm{NO}$ bioequivalents that are peripherally converted into bioactive NO. However, these results could not be replicated by Lauer et al (144) who reported no vasodilatory effect following intra-arterial administration of $\mathrm{NaNO}_{2}$ into healthy volunteers. This may relate to a shorter duration of nitrite infusion, or the need for nitrite to undergo metabolic conversion before becoming vasoactive. A careful comparison of the route of administration, the concentration and total dose of nitrite is needed to better understand its role (45).

Various possible in vivo pathways by which nitrite is reduced to NO have been investigated (figure 4). Nitrite can form NO non-enzymatically under acidic and/or ischemic conditions (251). Using ${ }^{15} \mathrm{~N}$-labelled nitrite to identify the source of NO, and enzyme inhibitors to exclude other pathways, NO generation was explained by a reaction of spontaneous disproportionation; however, the in vivo relevance of this pathway remains uncertain. Dedicated nitrite reductases are present in bacteria, but are lacking in humans. Nonetheless, certain mammalian enzymes show some nitrite reductase activity beyond their normal physiologic function. As an alternative to non-enzymatic reduction, proteins from the hemeglobin family (89) or from pterin-based molybdenum enzymes (149) may catalyze the $\mathrm{NO}_{2}^{-}-$ reductase reaction to $\mathrm{NO}$. An in vitro reaction of $\mathrm{NO}_{2}^{-}$with human deoxyhemoglobin forms NO and methemoglobin while an intra-arterial nitrite infusion produces, after several circulation times, a vasodilatory effect in healthy volunteers (60). Myoglobin, both in the heart and vasculature $(105,185)$, also has significant $\mathrm{NO}_{2}{ }^{-}$-reductase activity, as do heme protein-containing enzymes such as the mitochondrial electron transport chain cytochromes $(17,49,138)$, the cytochrome P450 family of microsomal heme proteins $(151)$, and aldehyde 
dehydrogenase (ALDH2), a mitochondrial enzyme involved in ethanol inactivation that has also been linked to the bioactivation of organic nitrates $(13,51)$. Even eNOS and soluble guanylate cyclase (sGC), being heme-based enzymes, may have possible nitrite reductase activity, thereby offering an important alternative source of NO outside the conventional Larginine pathway $(8,87)$.

Given that $\mathrm{Hb}$ is an effective scavenger of $\mathrm{NO}$, the possibility of a heme-independent pathway of NO synthesis from nitrite merits consideration as the in vivo relevance of nitrite reduction by heme-based enzymes may be challenged by the need for the newly synthesized $\mathrm{NO}$ to escape from this scavenging. The two most studied $\mathrm{NO}_{2}{ }^{-}$-reducing molybdenum-based enzymes are xanthine oxidoreductase (XOR) and aldehyde oxidase (149). The former plays a critical role in purine and pyrimidine catabolism, catalyzing oxidation of hypoxanthine to xanthine, and xanthine to uric acid. As it also reduces $\mathrm{O}_{2}$ to $\mathrm{H}_{2} \mathrm{O}_{2}$ and $\mathrm{O}_{2}{ }^{-}$XOR is a key enzyme in the process of oxidative injury. XOR can catalyze reduction of $\mathrm{NO}_{3}^{-}$to $\mathrm{NO}_{2}^{-}$, and $\mathrm{NO}_{2}^{-}$to $\mathrm{NO}$ under anerobic conditions; this can be blocked by the XOR-inhibitor, oxypurinol (152). Similarly, aldehyde oxidase, a cytosolic enzyme involved in biotransformation of drugs and xenobiotics, also has significant in vitro $\mathrm{NO}_{2}^{-}-$ reductase activity (150).

\section{(ii) Release from pre-formed storage pools}

Attempting to solve the apparent paradox of the NO scavenging process being too rapid and effective to allow this short half-life molecule to exert its physiologic effects, it has been suggested that, depending on the oxygenation state of $\mathrm{Hb}$, NO may either react with oxyHb to be oxidized to $\mathrm{NO}_{3}{ }^{-}$, or can bind to the deoxygenated form to generate a nitrosyl-adduct $(\mathrm{NO}-\mathrm{Hb})$ that subsequently reacts with thiol groups to produce S-nitrosohemoglobin (SNO$\mathrm{Hb})(121,191,225)$. SNO-Hb is more stable and has a longer half-life than NO, and its 
administration can evoke a hypotensive response suggesting it acts as both carrier and donor of NO bioequivalents (figure 3).

Other reservoirs of potential nitric oxide bioactivity include S-nitrosoalbumin (224), tissue nitrite, S-nitrosothiols (RSNO), N-nitrosamines (RNNO), and dinitrosyl iron complexes (DNIC). Their concentrations vary in different pathophysiologic states, typically showing marked elevation compared to basal levels in acute inflammation and reduction in the more chronic setting. Although little is known about their in vivo relevance, they may act as signalling molecules or storage forms of $\mathrm{NO}(43,73,237)$. Similar NO storage forms are found in other compartments such as the vascular wall (203).

Regardless of location, all these compounds may be activated to release NO under certain conditions, and to contribute to the body pool of NO-related metabolites. Opinion still remains divided as to the in vivo importance of these mechanisms $(90,118,198)$. A mitochondria-targeted S-nitrosothiol was recently shown to selectively induce NO production and S-nitrosylation (addition of an $\mathrm{NO}^{+}$group to a protein thiol to form a nitrosothiol) at the

mitochondrial level, producing vascular relaxation of pre-contracted aortic rings and protecting against ischemia-reperfusion (197). Molecules able to enhance trans-nitrosation reactions, transferring NO from one cysteine residue to another, constitute an emerging area of research in the field of drug design (86).

\section{d) NO metabolism}

The in vivo fate of NO is highly complex; several catabolic pathways exist (figure 5), with varying relevance in different body compartments $(27,131)$. In vitro, NO rapidly reacts with $\mathrm{O}_{2}$ to form nitrogen dioxide $\left(\mathrm{NO}_{2}\right)$. In the presence of $\mathrm{NO}$ at low concentration, the latter reacts with water to form equal amounts of nitrite and nitrate. At higher NO concentrations, $\mathrm{NO}_{2}$ reacts with another $\mathrm{NO}$ molecule to form dinitrogen trioxide $\left(\mathrm{N}_{2} \mathrm{O}_{3}\right)$, which hydrolyses to form nitrite. In plasma, in the presence of $\mathrm{O}_{2}$, the principal reaction is formation of $\mathrm{NO}_{2}{ }^{-}$ 
(115). Whether this is through autoxidation of NO, reaction with the plasma multi-copper oxidase ceruloplasmin (220), or oxidation by the mitochondrial cytochrome c oxidase in vascular cells is currently unclear $(192,218,230)$. The situation differs in whole blood where the relatively high amount of oxyHb favours biotransformation of $\mathrm{NO}$ to $\mathrm{NO}_{3}{ }^{-}$with concomitant formation of methemoglobin (27). This $\mathrm{Hb}$ reaction is considered by some as the primary catabolic process responsible for NO removal $(107,124)$. A similar reaction with oxymyoglobin (to generate metmyoglobin and $\mathrm{NO}_{3}{ }^{-}$) has been recently proposed as a crucial regulatory step of NO inactivation in muscle $(40,79)$. However, other studies have shown that this reaction only takes place in conditions of excess NO (192).

NO can also react with superoxide to produce peroxynitrite (ONOO-). The rapidity of this reaction, some 3-4-fold faster than $\mathrm{O}_{2}{ }^{-}$dismutation by superoxide dismutase, makes ONOOformation a major potential disposal pathway of NO reactivity (92), though this does depend on the rate of tissue superoxide production. $\mathrm{ONOO}^{-}$itself may trigger oxidation or nitration reactions with various cellular targets modulating their biological activities, and is eventually converted into nitrate or nitrite (228).

Nitrate and nitrite were long considered stable end-products of NO catabolism, however both are now recognized to be subject to further biotransformation $(78,131,226)$. Highly reactive NO by-products (reactive nitrogen species) can react with protein thiol (-SH) groups to form S-nitrosothiols such as S-nitrosoalbumin, S-nitrosoglutathione and S-nitroso-hemoglobin (131), or with amines to generate N-nitrosamines. The physiologic significance of RNNOs is presently unknown, but concentrations change rapidly in response to an acute oxygen shortage (43). NO itself can directly react with metals to generate metal nitrosyls, e.g. NO$\mathrm{Hb}$. In addition to nitrosation, RSNOs may also be produced by oxidative nitrosylation. This reaction is mediated by generation of thiyl radicals (RS) that may be derived from interaction of thiols with oxidants such as peroxynitrite (43). NO metabolism changes under hypoxic conditions, with greater production of metal nitrosyls, RSNOs and RNNOs (180). Some of 
these products share some of the biologic properties of NO (226) and may possess the important biological functions of storing and transporting NO. Moreover, S-nitrosylation of thiol groups is a widespread post-translational redox-based protein modification. Similar to phosphorlyation, this exerts control over many protein classes in various physiologic and pathophysiologic conditions $(108,157)$.

\section{e) Half-life of NO}

The process of NO transfer to its target remains incompletely understood. NO has high reactivity and a very short half-life, with measured blood levels being too low to likely exert any physiologically relevant effect (159). From in vitro studies, the half-life ranges from as little as $10^{-6}$ seconds to as much as 11.5 seconds (100). Mathematical modelling estimates an in vivo half-life of about $2 \mathrm{~ms}$ (158). Such a short half-life plus the rapid intravascular scavenging of NO has to be reconciled with the prominent autocrine and paracrine roles this molecule is believed to play in cellular physiology. Liao et al (154) proposed the existence of intravascular erythrocyte-free zones generated by blood flow that may increase the NO halflife by several orders of magnitude due to reduced local NO scavenging, thus allowing the molecule to exert its biologic functions. Another possibility is the concept of stored NO bioactivity $(66,221)$, as outlined above.

To summarize, referring to the half-life of free NO may no longer be relevant given the rapidity of its transformation and interchange between different metabolites, many of which are longer lived than the parent molecule. A more complex system appears to be in place, in which the short half-life of $\mathrm{NO}$ itself is important in limiting the action of the molecule to its site of formation and to enable local signalling (autocrine and paracrine levels), while downstream biotransformation reactions make economical use of the NO produced as well as contributing to distant signalling (endocrine level).

\section{Nitric oxide and cardiovascular homeostasis}




\section{a) Nitric oxide as a regulator of vascular homeostasis}

$\mathrm{NO}$ is a core physiologic regulator of many cardiovascular processes, including platelet aggregation and adhesion, myocardial contractility, vascular permeability and tone $(187,243)$. NO is essential for both global regulation and regional distribution of blood flow and pressure. Dysregulation of the NO system thus likely plays a fundamental role in many pathophysiologic conditions ranging from essential hypertension and atherosclerosis to the hypotension seen in acute shock states (243).

Nitric oxide is a key contributor to new vessel formation: in endothelial cells, VEGF induced NO production via eNOS that, in turn, mediated angiogenesis (83). iNOS-derived NO may also have a role in angiogenesis (178). Besides being an effector of VEGF activation, NO also enhances growth factor synthesis in numerous cell types, mimicking the classical hypoxic stimulus (71). Thus, NO appears to act both as an upstream and a downstream mediator of VEGF-dependent angiogenesis.

\section{b) Mechanisms underlying the vasodilatory action of NO}

NO regulates blood pressure and flow through its effects on vascular smooth muscle tone. The shear stress generated by flowing blood against the endothelial surface triggers production of NO both basally (114), and in response to mechanostimulation (222). This increase in NO production is nonlinear with respect to shear stress (14). Of note, laminar blood flow (which increases shear stress) increases NO production whereas disturbed flow (causing low and oscillating shear stress) inhibits release of NO and fails to upregulate NOS (58).

Being small and lipophilic, NO rapidly diffuses across membranes to reach vascular smooth muscle cells. Its main mechanism of action is mediated by nitrosylation of the heme-iron within sGC, leading to increased synthesis of cyclic GMP (cGMP) (243). This, in turn, 
activates protein kinases that modulate myosin light chain kinase and phosphatase activities, resulting in less phosphorylation of myosin and, eventually, vasorelaxation (143). NO can also cause vasodilation via cGMP-mediated opening of calcium-sensitive $\left(\mathrm{K}_{\mathrm{Ca}}\right)(10)$ and ATP-sensitive ( $\mathrm{K}_{\text {ATP }}$ ) (179) potassium channels. When these ion channels open, the outward efflux of potassium hyperpolarizes the plasma membrane, reducing vascular tone. $\mathrm{NO}$ also activates $\mathrm{K}_{\mathrm{ATP}}$ and $\mathrm{K}_{\mathrm{Ca}}$ channels in a cGMP-independent manner through direct $\mathrm{S}$ nitrosylation $(28,129)$. NO may contribute to the regulation of intracellular free $\mathrm{Ca}^{2+}$ levels, either via cGMP-dependent inhibition of calcium influx through L-type $\mathrm{Ca}^{2+}$ channels (23), and/or via increased $\mathrm{Ca}^{2+}$ removal from the cytoplasm. The latter can occur by accelerating the $\mathrm{Na}^{+} / \mathrm{Ca}^{2+}$ exchanger (84), or by increasing sequestration into intracellular stores via the sarcoplasmic/endoplasmic reticulum $\mathrm{Ca}^{2+}$ ATPase $(2,56)$. This effect may be important as the constitutive isoforms of NOS are calcium-calmodulin-regulated (216). An increase in intracellular $\mathrm{Ca}^{2+}$ activates calmodulin leading to NO synthesis. Thus, it could be postulated that reduced intracellular levels of free calcium resulting from increased NO levels could reduce the amount of iNOS-generated NO, contributing to the fine tuning of NO levels. (figure 6)

In health, eNOS mediates most of the hemodynamic actions of NO, contributing to blood flow regulation between different vascular beds according to their varying metabolic needs $(177,243)$. NO derived from iNOS is traditionally considered to be primarily responsible for the vascular hyporeactivity and hypotension seen in inflammatory states (235). However, emerging data indicate an important role for nNOS-derived NO in basal microvascular tone regulation while eNOS-derived NO regulates changes in tone in response to agonists or shear stress (171). This suggests a potentially independent regulation of basal and stimulated blood flow. 


\section{Hypoxic vasodilation to improve coupling of oxygen delivery and utilization}

\section{(a) Evidence for the involvement of NO}

Under hypoxemic conditions, a vasodilatory response occurs, augmenting blood flow in an attempt to maintain $\mathrm{O}_{2}$ delivery. Given its importance in the regulation of cardiovascular homeostasis, NO likely plays a key role. An association between NO and hypoxic vasodilation was first described in 1989 (196). This response was endothelium-dependent and significantly reduced by administration of $\mathrm{oxyHb}$, acting as a potent $\mathrm{NO}$ scavenger. Tenfold higher levels of circulating NO products were found in residents of the Tibetan plateau compared to sea-level dwellers (76). This was associated with increased resting forearm blood flow suggesting an adaptive role that offsets the $\mathrm{O}_{2}$ lack caused by high altitude. In volunteers hypoxemia-induced increases in forearm blood flow were blocked by the nonspecific NOS inhibitor, L-NMMA (24). In awake sheep, hypoxemia-induced increases in cerebral blood flow and falls in cerebral vascular resistance were reversed by the sGC inhibitor, methylene blue (119).

\section{(b) Alternative theories}

Apart from its role as an energy source for cellular metabolic activity, ATP has important signaling characteristics, particularly in situations of reduced energy supply such as hypoxia. ATP release occurs in all major cell types (162), including endothelial cells, vascular smooth muscle cells and circulating red blood cells. In the blood vessel lumen, ATP levels increase during hypoxia (21) or conditions of increased shear stress (26). Precise mechanisms responsible for release are, at present, incompletely understood. Ellsworth et al have postulated a key role for the red blood cell (RBC) in sensing hypoxia (74) and modulating vascular tone via active release of ATP (75). Blood flow is significantly augmented, either through direct purinergic signaling or by inducing synthesis of vasoactive metabolites such as NO. These pathways do appear to intersect and interact with each other; indeed, NO can inhibit ATP release from RBCs (181) while nitrite enhances erythrocyte ATP synthesis and release during hypoxia (46). 


\section{(c) NO and control of metabolism}

In tandem with its role in hypoxic vasodilation, NO has potent inhibitory effects upon cellular metabolism that are significantly enhanced under hypoxic conditions $(53,59)$. NO potently and reversibly reduces mitochondrial membrane potential (213) by competing with $\mathrm{O}_{2}$ at $\mathrm{CcO}$ (34). As less competition occurs in the presence of hypoxia, after an initial rapid (albeit reversible) inhibition of this enzyme, a potentially irreversible inhibition of Complex I occurs through nitrosylation and nitration that is also accelerated by hypoxia $(52,81)$. For nitrosothiols and peroxynitrite to interact with Complex I, prior transition of the enzyme from its active $(A)$ to its deactive (D) state is necessary, as only the D-form is susceptible to inactivation by these agents. Transition of Complex I from A to D preferentially occurs during hypoxia (85). This process may initially confer some degree of protection, reducing the amount of free radicals produced upon re-oxygenation, but may also initiate pathophysiological modifications of mitochondrial activity. Taken together, under conditions of reduced $\mathrm{O}_{2}$ availability NO mediates an important compensatory response through both enhancing supply and suppressing metabolic demand (figure 6).

Other important effects of NO on intermediary metabolism are mediated through ONOOdependent activation of the AMPK system, or by direct nitrosation of critical thiols of target enzymes (122). The link between NO and the AMPK system involves different levels of regulation; for example, silencing of AMPK caused a decrease in cellular eNOS content (57). In particular, NO can limit energy-consuming anabolic processes such as hepatic gluconeogenesis and glycogen synthesis while inducing energy-producing catabolic pathways via increased expression of transmembrane carbohydrate transporters and a higher glycolytic flux $(7,153)$. Over a longer time-scale, NO stimulates biogenesis of functionally active mitochondria (54). NO may also be an important modulator of the adaptive response to hypoxia; by redistributing $\mathrm{O}_{2}$ within cellular compartments and between neighbouring cells and interfering with the stabilization process of HIF-1 $\alpha$, it 
allows fine-tuning of cellular metabolism (99). Altered levels of NO and ROS likely impinge upon oxygen-sensing pathways. In a variety of cell types, NO stabilized HIF-1 $\alpha$ protein and provoked HIF-1 target gene expression under normoxia (36). Whether this is due to NO itself or to a reactive intermediate, and whether or not the mechanism is cGMP-dependent is under active investigation (37). It does appear that the ability of NO to stabilize HIF-1 $\alpha$ depends to some extent on the formation of co-signals, such as, for instance, superoxide and the consequent production of peroxynitrite.

Notwithstanding the above findings, some authors reported no impact of NO modulation on whole body (63) or myocardial (136) oxygen consumption. By contrast, others did find a modulating effect on whole body oxygen consumption (217). The negative studies used non-selective NOS inhibition but did not entertain the possibility that NO may be generated by alternate pathways such as nitrite reduction or release from RSNO. Moreover, the lack of effect after administering the NO donor sodium nitroprusside, or authentic NO, may be explained by the potent scavenging properties of haemoglobin and myoglobin.

Conceivably, the effect of NO on oxygen delivery and consumption may be tissue-specific. In the brain, NO synergized with hypoxia to induce necrotic death via $\mathrm{CcO}$ inhibition in both neurons (120) and glia (170). NO-mediated inhibition of CcO may thus induce an adaptive state of reduced $\mathrm{O}_{2}$ consumption compensated for by increased glycolytic flux, or it may lead to a critical reduction in ATP production and cell death. The overall impact likely depends on the relative contribution of each process; this is turn depends on the extent and rate of metabolic perturbation and, perhaps, the cell type affected.

\section{(d) NO and microRNAs}

The interplay between NO and microRNA signalling is intriguing. Such cross-talk may connect a very fast and ubiquitous signalling pathway for the acute response to hypoxia with the master regulator of chronic hypoxia. This was recently demonstrated in studies of the mechanisms of ischemic or hypoxic myocardial preconditioning (209). miR-21, a 
microRNA induced in vascular tissue by shear stress, increased NO availability through phosphorylation of eNOS (242). Conversely, a NO donor modulated production of miR-21 and other microRNAs, thereby regulating smooth muscle cell contraction (137). Brief bursts of myocardial ischemia induced miR-1, miR-21 and miR-24; this, in turn, induced eNOS mRNA and upregulated eNOS protein, whereas no effect was seen on iNOS. This miRinduced, eNOS-derived NO had cardioprotective effects against ischemia-reperfusion injury, possibly by restoring the $\mathrm{O}_{2}$ supply/demand balance (248).

Very recently, another aspect of miR-mediated regulation of the NO pathway was discovered: a well-known paradox of iNOS-derived NO is that cytokine stimulation can upregulate iNOS gene expression $>2000$-fold but, in some tissues, the increase in NO levels was far less (167). miR-939 decreased cytokine-induced iNOS protein expression but with no effect on iNOS mRNA levels or stability, thereby contributing to posttranslational silencing through direct binding to the iNOS gene (93). Similarly, increases in miR-146a activity inhibited of LPS-induced iNOS expression and NO production (64). These findings have been interpreted as an endogenous protective mechanism against the untoward consequences of prolonged iNOS overexpression.

\section{(e) NO and the renin-angiotensin system}

The renin-angiotensin system (RAS) is an important regulator of blood flow and pressure through renal, vascular and central mechanisms (97). The classical pathway involves binding of angiotensin II to the angiotensin II type 1 receptor (AT1), to exert inotropic and vasocontrictor actions through increasing intracellular free calcium. The type 2 receptor (AT2) serves to counterbalance activation of the AT1 pathway; one of the main pathways associated with AT2 activation is stimulation of NO production (47). AT2 activation significantly attenuated mitochondrial respiration, and this was reversed by the NOS inhibitor L-NAME (1). 


\section{(f) NO levels in hypoxia: balance of synthesis and metabolism}

The NO concentration at any given location represents the balance between local synthesis and metabolism/elimination. During hypoxic vasodilation, the rise in NO levels may derive from increased production via NOS isoforms, and/or increased NO synthesis from alternate pathways (e.g. nitrite reduction or RSNO release), and/or reduced elimination, e.g. by conversion to $\mathrm{NO}_{2}{ }^{-}$or $\mathrm{NO}_{3}{ }^{-}$(figure 7). An alternative (or perhaps concurrent) mechanism is of vasodilation due to other factors such as ATP release by RBCs; the resulting increase in shear stress increases NO production which then further enhances the vasodilatory response.

\section{(i) Does hypoxia increase NO production by NOS?}

NOS-related NO production increases during hypoxia. In dogs, NOS inhibition reversed hypoxemia-induced tachycardia, hypotension and increases in cardiac output (12), findings subsequently replicated in human volunteer studies $(25,48,236)$. However, NOS inhibition also accentuated the hypoxia-induced rise in pulmonary vascular resistance (25).

Given the rapidity (seconds to minutes) of hypoxic vasodilation, the initial increase in NO synthesis is likely to be primarily mediated by a constitutively expressed NOS isoform. $\mathrm{O}_{2}$ regulates transcription of eNOS (11) and possibly nNOS (19). With prolonged hypoxia, NO levels progressively rise; in an ex vivo macrophage model iNOS mRNA was detected after 1.5 hours of hypoxia (9). HIF-1 may influence with iNOS expression under hypoxic conditions (125). In some cell types such as macrophages, hypoxia cannot by itself induce iNOS expression, whereas the synergistic combination of hypoxia and interferon- $y$ was a potent inducer (172). In other cell types (e.g. cardiomyocytes), hypoxic activation of the HIF-1 pathway could upregulate iNOS expression by itself, though this was significantly amplified with interleukin-1 $\beta$ (125). In pulmonary artery endothelial cells, hypoxia alone did not induce iNOS expression, but it significantly modulated cytokine induction of the gene, prolonging the half-life of cytokine-induced iNOS mRNA from 6 to 17 hours (250). 
However, hypoxia itself can induce expression of inflammatory cytokines (133) which then can activate iNOS. Thus, a more complex scenario probably exists in vivo with coparticipation of all three isoforms.

The oxygen atom in NO and citrulline is derived from molecular oxygen, regardless of synthesis by constitutive or inducible isoforms of NOS (146). Hypoxia could attenuate the NO component of endothelium-dependent vascular relaxation, likely due to decreased NO production secondary to oxygen depletion $(123,200)$. The apparent $\mathrm{Km}$ values for oxygen were 17, 6 and $5 \mathrm{mmHg}$ for neuronal, endothelial and inducible isoforms of NOS respectively(201). These values are close to the $\mathrm{Km}$ values of other enzymes that utilize $\mathrm{O}_{2}$ as a substrate, e.g. CcO. As the neuronal isoform shows a higher $\mathrm{Km}$ value for $\mathrm{O}_{2}$, it is thus more sensitive to the prevailing oxygen concentration.

Despite its apparent simplicity, the likelihood that hypoxic vasodilatation can be predominantly explained by de novo NOS synthesis presents at least three major contradictions. Given that NOS-derived NO synthesis requires molecular $\mathrm{O}_{2}$, it seems counter-intuitive in situations of $\mathrm{O}_{2}$ lack to record an increase in NO production. Indeed, some in vitro experiments report reductions in eNOS mRNA expression and decreased NO production during hypoxia $(155,200,245)$. These results conflict with those cited above and may relate to the degree of hypoxia (or anoxia) experienced, the varying $\mathrm{O}_{2}$ sensitivity of the different cells/tissues studied, and/or a possible biphasic nature of events relating to the time course of the overall response (e.g. feedback inhibition of NOS expression secondary to an acute initial increase in NO availability, followed by a gradual increase in expression as hypoxia persists). Nevertheless, these studies raise important concerns regarding the true significance of NOS-derived NO in hypoxia. Secondly, increased arginase activity during hypoxia is a well-known process $(139,163)$, and this reduces the amount of substrate available for the reaction by NOS. 
A more complex regulation of NO synthesis from NOS may exist during hypoxia. In a rodent model of chronic hypoxia, exposure to $10 \% \mathrm{O}_{2}$ significantly increased pulmonary eNOS expression, in addition to an increase in ADMA concentration, reduced DDAH, (the enzyme responsible for ADMA disposal) and reduced tissue nitrate/nitrite (NOx) concentrations (175). They postulated that hypoxia reduces DDAH activity that, in turn, increases ADMA concentrations that leads to eNOS inhibition and reduced synthesis of NO. Finally, in several studies NOS inhibition could only partially reverse hypoxic vasodilation, thus other mechanisms must be implicated $(35,148)$.

(ii) Does hypoxia increase NO release from SNO-Hb and other NO storage forms? Stamler's theory for hypoxic vasodilation demands a central role for erythrocytes in matching blood flow to local metabolic demands. The affinity of hemoglobin for NO is similar to that for $\mathrm{O}_{2}$, i.e. high in the relaxed deoxygenated state, and low in the tense oxygenated state (225). A cysteine residue on the hemoglobin $\beta$-chain reacts with NO to form a nitroso-adduct (SNO-Hb) that acts as a carrier of NO bioactivity. Erythrocytes thus act as $\mathrm{O}_{2}$ sensors to control regional blood flow. Erythrocytes could rapidly relax thoracic aortic rings from both rabbits and mice under hypoxic but not normoxic conditions, though this relaxation could be inhibited by either depletion of SNO-Hb or SGC blockade (70).

(iii) Does hypoxia increase reduction of nitrite to NO?

The findings of an increased concentration of NO during hypoxic vasodilation, full reversal of these hemodynamic effects by SGC inhibition but not by NOS blockade, a strict $\mathrm{O}_{2}$ dependence of the NOS reaction, and the possibility that $\mathrm{NO}_{2}^{-}$can be converted to $\mathrm{NO}$, particularly under acidic conditions, suggest that nitrite itself may act as a NO-equivalent donor during hypoxia $(3,176)$. cGMP-dependent nitrite vasodilation and the rise in measured NO have been interpreted as evidence for the involvement of a NO-mediated relaxation, rather than a direct $\mathrm{NO}_{2}{ }^{-}$effect. Intravenous infusion of sodium nitrite (1 
$\mu \mathrm{mol} / \mathrm{min}$ ) into healthy volunteers increased forearm blood flow and reduced pulmonary artery pressure only under hypoxemic $\left(12 \% \mathrm{O}_{2}\right)$ conditions, but was not related simply to an increase in plasma nitrite concentration (116). These data are consistent with a direct extravascular metabolism of $\mathrm{NO}_{2}{ }^{-}$to $\mathrm{NO}$ to exert hypoxia-associated bioactivity. Whether endogenous nitrite concentrations are sufficient to cause similar hemodynamic effects remains uncertain at present.

Of the many different mammalian molecules with nitrite reductase activity (figure 4), the most extensively studied is hemoglobin. Addition of erythrocytes induced a left shift in the vasodilatory dose-response curve and cGMP accumulation in response to nitrite but only under hypoxic conditions (61). This could be inhibited by the NO scavenger, C-PTIO. Thus, $\mathrm{NO}_{2}^{-}$exerted a higher vasodilatory effect when deoxygenated $\mathrm{Hb}$ was present, again emphasizing the role of $\mathrm{NO}$-dependent mechanisms in hypoxic vasodilation.

Hemoglobin may be an important physiologic $\mathrm{O}_{2}$ sensor that can modulate vascular tone by (i) scavenging excess $\mathrm{NO}$ and (ii) increasing local blood flow through $\mathrm{NO}$ generation from nitrite when $\mathrm{O}_{2}$ content is reduced. This theory remains controversial because of the avid NO-scavenging properties of hemoglobin to the point that it has been argued that this phenomenon has minimal, if any, in vivo relevance (6). The Gladwin group countered with a recent ex vivo study using rat vascular rings (117) wherein the balance between the NOscavenging and generating properties of hemoglobin was specifically targeted during both normoxia and hypoxia. They found that nitrite displays a particular interaction with deoxyhemoglobin that promotes vasodilation despite its scavenging properties.

Myoglobin can also act as a nitrite reductase, with NO being produced in vitro by reaction between $\mathrm{NO}_{2}^{-}$and myoglobin (199). This conversion was significantly reduced in cardiac tissue taken from a myoglobin knockout mouse model but restored by adding exogenous myoglobin. Under hypoxic conditions in vitro (238) and ex vivo (240) eNOS also displays 
nitrite reductase activity. As for the pterin-based enzymes, both xanthine oxidoreductase $(174,240)$ and aldehyde oxidase (195) are sources of $\mathrm{NO}_{2}^{-}$reduction, particularly during coexisting hypoxia and acidosis.

The apparently conflicting theories of $\mathrm{NO}_{2}^{-}$reduction and S-nitrosothiols acting as non-NOS dependent sources of NO, and as regulators of local blood flow under both physiologic and hypoxic/ischemic conditions, may be reconciled $(42,77)$. Under physiologic conditions, nitrite is not directly reduced to NO but rather modulates many signalling pathways, including SGC activation. It also induces post-translational modifications normally associated with $\mathrm{NO}$, such as the formation of nitroso- and nitrosyl species (42). $\mathrm{NO}_{2}^{-}$may therefore exert its signalling functions directly, without the need for intermediary formation of free NO. Hypoxia markedly potentiates tissue $\mathrm{NO}$ production from $\mathrm{NO}_{2}^{-}$in a dosedependent manner (77). This occurs particularly in heart, liver and vascular tissue, with multiple heme, iron-sulfur cluster and molybdenum-based reductases distributed among distinct subcellular compartments acting in a multifactorial and cooperative manner to catalyze the reaction. Acute hypoxia also reduces $\mathrm{NO}_{2}{ }^{-}$concentrations yet enhances formation of NO metabolites such as RSNOs and RNNOs in an NO-independent manner. This suggests a pathway that generates bioactive $\mathrm{NO}$ metabolites directly from $\mathrm{NO}_{2}^{-}$. In this paradigm, conversion of $\mathrm{NO}_{2}^{-}$to $\mathrm{NO}$ and the storage of $\mathrm{NO}$ bioactivity as $\mathrm{RSNO}$ may both be constituents of a more complex regulatory mechanism of interaction of multiple NOrelated species. The differences in oxygen dependence of nitrite reductase activity in tissues (exponential) versus red blood cells (optimum around the p50) suggest that the regulatory range of the latter may operate at intermediate levels of hypoxia whereas the former predominates as $\mathrm{PO}_{2}$ drops further.

(iv) Does hypoxia reduce NO metabolism by cytochrome c oxidase? Moncada's group suggested that the hypoxia-induced increase in NO is due to reduced elimination rather than increased production $(186,234)$. Plausibility has been tested in a 
computational model of brain $\mathrm{O}_{2}$ transport and metabolism (205), with description of the kinetic parameters that link decreased $\mathrm{NO}$ metabolism by $\mathrm{CcO}$ with low $\mathrm{O}_{2}$ concentrations. They showed in L-arginine-supplemented iNOS-overexpressing cells that the capacity of $\mathrm{CcO}$ to metabolize $\mathrm{NO}$ was diminished at low $\mathrm{O}_{2}$ tensions, and that this correlated with both the enzyme's redox state and consequent sGC activation. The same effect was seen when the redox state was altered by cyanide rather than hypoxia. Whereas NOS inhibition was effective at reducing $\mathrm{NO}$ levels, $\mathrm{NO}_{2}{ }^{-}$administration had no effect on $\mathrm{NO}$ release at any $\mathrm{O}_{2}$ tension $(186,234)$. NO production was also similar at all $\mathrm{O}_{2}$ tensions, regardless of whether $\mathrm{CcO}$ was oxidized or reduced (234). They thus concluded that $\mathrm{CcO}$ (in its oxidized state) constantly inactivates NO, thus regulating its intracellular concentration. However, in the reduced state seen in hypoxia, impaired inactivation would account for the increase in NO. This leads to local vasodilatation with improvements in oxygen delivery and a concurrent reduction in oxygen consumption due to direct inhibition of $\mathrm{CcO}$, thereby facilitating the matching of delivery to needs under hypoxic conditions. Further studies are needed to demonstrate the in vivo relevance of these findings.

\section{Conclusions}

Hypoxic vasodilatation is an adaptive response that involves elevations in local NO concentrations in response to an acute reduction in arterial $\mathrm{PO}_{2}$. This both increases blood flow to restore $\mathrm{O}_{2}$ delivery and also modulates local metabolic requirements, thus attempting to re-balance an acute oxygen supply-demand mismatch. Several mechanisms are implicated (Figure 7) including increased NO synthesis from NOS, increased reduction of nitrite to NO by heme- or pterin-based enzymes, increased release of NO from NO storage forms, and reduced deactivation by mitochondrial cytochrome c oxidase. Many of these mechanisms have been shown either in in vitro/ex vivo conditions or by utilization of pharmacologic dosing regimens, so the question remains as to their in vivo (patho)physiologic relevance. While tissue hypoxia can result from decreases in arterial $\mathrm{PO}_{2}$, 
blood flow or hemoglobin concentration (15), the adaptive mechanism for each form of hypoxia need not be identical. A recent animal study (62) demonstrated that NOS inhibition did not blunt the increase in myocardial blood flow during acute normovolemic hemodilution, and suggested, at least in this form of tissue hypoxia, that NO did not mediate vasodilation. Further work is needed to fully elucidate the multiple and varied roles of NO under hypoxic conditions, and to integrate these into an overall picture. 


\section{Acknowledgements:}

We thank Carlotta Mozzana for the invaluable assistance with the artwork.

\section{Sources of funding:}

This work was undertaken at UCLH/UCL who received a proportion of funding from the Department of Health's NIHR Biomedical Research Centres funding scheme. MU was supported by a Physiology Award from the Accademia Nazionale dei Lincei (Roma)/Royal Society (London).

\section{Author disclosure statement:}

The authors declare no competing financial interests.

\section{Glossary of non-standard Abbreviations and Acronyms}

ADMA: asymmetric dimethylarginine; ALDH2: aldehyde dehydrogenase; AMPK: AMPactivated protein kinases; $\mathrm{AO}$ : aldehyde oxidase; $\mathrm{CcO}$ : cytochrome c oxidase; cGMP: cyclic GMP; DO2: oxygen delivery; Hb: haemoglobin; HIF-1: hypoxia inducible factor-1; N2O3: dinitrogen tetroxide; NO: nitric oxide; NO2-: nitrate; NO2: nitrogen dioxide; NO3-: nitrate; NOS: nitric oxide synthase; O2.-: superoxide radical; ONOO-: peroxynitrite; PO2: partial pressure of oxygen; RNNO: N-nitrosamines; ROS: reactive oxygen species; RSNO: S-nitrosothiols; sGC: soluble guanylate cyclase; SNO-Hb: S-nitrosohemoglobin; VO2: oxygen consumption; XOR: xanthine oxidoreductase 


\section{References}

1. Abadir PM, Foster DB, Crow M, Cooke CA, Rucker JJ, Jain A, Smith BJ, Burks TN, Cohn RD, Fedarko NS, Carey RM, O'Rourke B, Walston JD. Identification and characterization of a functional mitochondrial angiotensin system. Proc Natl Acad Sci U S A 108: 14849-54, 2011.

2. Adachi T, Weisbrod RM, Pimentel DR, Ying J, Sharov VS, Schoneich C, Cohen RA. S-Glutathiolation by peroxynitrite activates SERCA during arterial relaxation by nitric oxide. Nat Med 10: 1200-7, 2004.

3. Agvald P, Adding LC, Artlich A, Persson MG, Gustafsson LE. Mechanisms of nitric oxide generation from nitroglycerin and endogenous sources during hypoxia in vivo. Br J Pharmacol 135: 373-82, 2002.

4. Alberti KG. The biochemical consequences of hypoxia. J Clin Pathol Suppl (R Coll Pathol) 11: 14-20, 1977.

5. Alderton WK, Cooper CE, Knowles RG. Nitric oxide synthases: structure, function and inhibition. Biochem J 357: 593-615, 2001.

6. Allen BW, Piantadosi CA. How do red blood cells cause hypoxic vasodilation? The SNO-hemoglobin paradigm. Am J Physiol Heart Circ Physiol 291: H1507-12, 2006.

7. Almeida A, Moncada S, Bolanos JP. Nitric oxide switches on glycolysis through the AMP protein kinase and 6-phosphofructo-2-kinase pathway. Nat Cell Biol 6: 45-51, 2004.

8. Alzawahra WF, Talukder MA, Liu X, Samouilov A, Zweier JL. Heme proteins mediate the conversion of nitrite to nitric oxide in the vascular wall. Am J Physiol Heart Circ Physiol 295: H499-508, 2008.

9. Angele MK, Schwacha MG, Smail N, Catania RA, Ayala A, Cioffi WG, Chaudry IH. Hypoxemia in the absence of blood loss upregulates iNOS expression and activity in macrophages. Am J Physiol 276: C285-90, 1999. 
10. Archer SL, Huang JM, Hampl V, Nelson DP, Shultz PJ, Weir EK. Nitric oxide and cGMP cause vasorelaxation by activation of a charybdotoxin-sensitive $\mathrm{K}$ channel by cGMP-dependent protein kinase. Proc Natl Acad Sci U S A 91: 7583-7, 1994.

11. Arnet UA, McMillan A, Dinerman JL, Ballermann B, Lowenstein CJ. Regulation of endothelial nitric-oxide synthase during hypoxia. J Biol Chem 271: 15069-73, 1996.

12. Audibert G, Saunier CG, Siat J, Hartemann D, Lambert J. Effect of the inhibitor of nitric oxide synthase, NG-nitro-L-arginine methyl ester, on cerebral and myocardial blood flows during hypoxia in the awake dog. Anesth Analg 81: 945-51, 1995.

13. Badejo AM, Jr., Hodnette C, Dhaliwal JS, Casey DB, Pankey E, Murthy SN, Nossaman BD, Hyman AL, Kadowitz PJ. Mitochondrial aldehyde dehydrogenase mediates vasodilator responses of glyceryl trinitrate and sodium nitrite in the pulmonary vascular bed of the rat. Am J Physiol Heart Circ Physiol 299: H819-26, 2010.

14. Balligand JL, Feron O, Dessy C. eNOS activation by physical forces: from short-term regulation of contraction to chronic remodeling of cardiovascular tissues. Physiol Rev 89: 481-534, 2009.

15. Barcroft J. ON ANOXÆMIA. The Lancet 196: 485-489, 1920.

16. Barouch LA, Harrison RW, Skaf MW, Rosas GO, Cappola TP, Kobeissi ZA, Hobai IA, Lemmon CA, Burnett AL, O'Rourke B, Rodriguez ER, Huang PL, Lima JA, Berkowitz DE, Hare JM. Nitric oxide regulates the heart by spatial confinement of nitric oxide synthase isoforms. Nature 416: 337-9, 2002.

17. Basu S, Azarova NA, Font MD, King SB, Hogg N, Gladwin MT, Shiva S, Kim-Shapiro DB. Nitrite reductase activity of cytochrome c. J Biol Chem 283: 32590-7, 2008.

18. Baue AE. MOF, MODS, and SIRS: what is in a name or an acronym? Shock 26: 43849, 2006.

19. Bauser-Heaton HD, Bohlen HG. Cerebral microvascular dilation during hypotension and decreased oxygen tension: a role for nNOS. Am J Physiol Heart Circ Physiol 293: H2193-201, 2007. 
20. Behm R, Mewes H, DeMuinck Keizer WH, Unger T, Rettig R. Cardiovascular and renal effects of hypoxia in conscious carotid body-denervated rats. J Appl Physiol 74: 2795-800, 1993.

21. Bergfeld GR, Forrester T. Release of ATP from human erythrocytes in response to a brief period of hypoxia and hypercapnia. Cardiovasc Res 26: 40-7, 1992.

22. Berne RM. Cardiac nucleotides in hypoxia: possible role in regulation of coronary blood flow. Am J Physiol 204: 317-22, 1963.

23. Blatter LA, Wier WG. Nitric oxide decreases [Ca2+]i in vascular smooth muscle by inhibition of the calcium current. Cell Calcium 15: 122-31, 1994.

24. Blitzer ML, Lee SD, Creager MA. Endothelium-derived nitric oxide mediates hypoxic vasodilation of resistance vessels in humans. Am J Physiol 271: H1182-5, 1996.

25. Blitzer ML, Loh E, Roddy MA, Stamler JS, Creager MA. Endothelium-derived nitric oxide regulates systemic and pulmonary vascular resistance during acute hypoxia in humans. J Am Coll Cardiol 28: 591-6, 1996.

26. Bodin P, Bailey D, Burnstock G. Increased flow-induced ATP release from isolated vascular endothelial cells but not smooth muscle cells. Br J Pharmacol 103: 1203-5, 1991.

27. Bohle DS. Pathophysiological chemistry of nitric oxide and its oxygenation byproducts. Curr Opin Chem Biol 2: 194-200, 1998.

28. Bolotina VM, Najibi S, Palacino JJ, Pagano PJ, Cohen RA. Nitric oxide directly activates calcium-dependent potassium channels in vascular smooth muscle. Nature 368: 850-3, 1994.

29. Boucher JL, Moali C, Tenu JP. Nitric oxide biosynthesis, nitric oxide synthase inhibitors and arginase competition for L-arginine utilization. Cell Mol Life Sci 55: 1015-28, 1999.

30. Boutilier RG. Mechanisms of cell survival in hypoxia and hypothermia. J Exp Biol 204: 3171-81, 2001. 
31. Boutilier RG, St-Pierre J. Surviving hypoxia without really dying. Comp Biochem Physiol A Mol Integr Physiol 126: 481-90, 2000.

32. Brand MD. The efficiency and plasticity of mitochondrial energy transduction. Biochem Soc Trans 33: 897-904, 2005.

33. Brown GC, Borutaite V. Nitric oxide and mitochondrial respiration in the heart. Cardiovasc Res 75: 283-90, 2007.

34. Brown GC, Cooper CE. Nanomolar concentrations of nitric oxide reversibly inhibit synaptosomal respiration by competing with oxygen at cytochrome oxidase. FEBS Lett 356: 295-8, 1994.

35. Brown IP, Thompson Cl, Belloni FL. Role of nitric oxide in hypoxic coronary vasodilatation in isolated perfused guinea pig heart. Am J Physiol 264: H821-9, 1993.

36. Brune B, Zhou J. The role of nitric oxide (NO) in stability regulation of hypoxia inducible factor-1alpha (HIF-1alpha). Curr Med Chem 10: 845-55, 2003.

37. Brune B, Zhou J. Nitric oxide and superoxide: interference with hypoxic signaling. Cardiovasc Res 75: 275-82, 2007.

38. Brunelle JK, Bell EL, Quesada NM, Vercauteren K, Tiranti V, Zeviani M, Scarpulla RC, Chandel NS. Oxygen sensing requires mitochondrial ROS but not oxidative phosphorylation. Cell Metab 1: 409-14, 2005.

39. Brunelle JK, Chandel NS. Oxygen deprivation induced cell death: an update. Apoptosis 7: 475-82, 2002.

40. Brunori M. Nitric oxide moves myoglobin centre stage. Trends Biochem Sci 26: 20910, 2001.

41. Bryan NS, Calvert JW, Gundewar S, Lefer DJ. Dietary nitrite restores NO homeostasis and is cardioprotective in endothelial nitric oxide synthase-deficient mice. Free Radic Biol Med 45: 468-74, 2008.

42. Bryan NS, Fernandez BO, Bauer SM, Garcia-Saura MF, Milsom AB, Rassaf T, Maloney RE, Bharti A, Rodriguez J, Feelisch M. Nitrite is a signaling molecule and regulator of gene expression in mammalian tissues. Nat Chem Biol 1: 290-7, 2005. 
43. Bryan NS, Rassaf T, Maloney RE, Rodriguez CM, Saijo F, Rodriguez JR, Feelisch M. Cellular targets and mechanisms of nitros(yl)ation: an insight into their nature and kinetics in vivo. Proc Natl Acad Sci U S A 101: 4308-13, 2004.

44. Bunn HF, Poyton RO. Oxygen sensing and molecular adaptation to hypoxia. Physiol Rev 76: 839-85, 1996.

45. Butler AR, Feelisch M. Therapeutic uses of inorganic nitrite and nitrate: from the past to the future. Circulation 117: 2151-9, 2008.

46. Cao Z, Bell JB, Mohanty JG, Nagababu E, Rifkind JM. Nitrite enhances RBC hypoxic ATP synthesis and the release of ATP into the vasculature: a new mechanism for nitrite-induced vasodilation. Am J Physiol Heart Circ Physiol 297: H1494-503, 2009.

47. Carey RM, Jin X, Wang Z, Siragy HM. Nitric oxide: a physiological mediator of the type 2 (AT2) angiotensin receptor. Acta Physiol Scand 168: 65-71, 2000.

48. Casey DP, Madery BD, Curry TB, Eisenach JH, Wilkins BW, Joyner MJ. Nitric oxide contributes to the augmented vasodilatation during hypoxic exercise. J Physiol 588: 373-85, 2010.

49. Castello PR, Woo DK, Ball K, Wojcik J, Liu L, Poyton RO. Oxygen-regulated isoforms of cytochrome c oxidase have differential effects on its nitric oxide production and on hypoxic signaling. Proc Natl Acad Sci U S A 105: 8203-8, 2008.

50. Chandel NS, Schumacker PT. Cellular oxygen sensing by mitochondria: old questions, new insight. J Appl Physiol 88: 1880-9, 2000.

51. Chen Z, Foster MW, Zhang J, Mao L, Rockman HA, Kawamoto T, Kitagawa K, Nakayama KI, Hess DT, Stamler JS. An essential role for mitochondrial aldehyde dehydrogenase in nitroglycerin bioactivation. Proc Natl Acad Sci U S A 102: 1215964, 2005.

52. Clementi E, Brown GC, Feelisch M, Moncada S. Persistent inhibition of cell respiration by nitric oxide: crucial role of S-nitrosylation of mitochondrial complex I and protective action of glutathione. Proc Natl Acad Sci U S A 95: 7631-6, 1998. 
53. Clementi E, Brown GC, Foxwell N, Moncada S. On the mechanism by which vascular endothelial cells regulate their oxygen consumption. Proc Natl Acad Sci U S A 96: 1559-62, 1999.

54. Clementi E, Nisoli E. Nitric oxide and mitochondrial biogenesis: a key to long-term regulation of cellular metabolism. Comp Biochem Physiol A Mol Integr Physiol 142: 102-10, 2005.

55. Coetzee A, Foex P, Holland D, Ryder A, Jones L. Effect of hypoxia on the normal and ischemic myocardium. Crit Care Med 12: 1027-31, 1984.

56. Cohen RA, Weisbrod RM, Gericke M, Yaghoubi M, Bierl C, Bolotina VM. Mechanism of nitric oxide-induced vasodilatation: refilling of intracellular stores by sarcoplasmic reticulum Ca2+ ATPase and inhibition of store-operated Ca2+ influx. Circ Res 84: 210-9, 1999.

57. Colombo SL, Moncada S. AMPKalpha1 regulates the antioxidant status of vascular endothelial cells. Biochem J 421: 163-9, 2009.

58. Cooke JP. Flow, NO, and atherogenesis. Proc Natl Acad Sci U S A 100: 768-70, 2003.

59. Cooper CE, Giulivi C. Nitric oxide regulation of mitochondrial oxygen consumption II: Molecular mechanism and tissue physiology. Am J Physiol Cell Physiol 292: C19932003, 2007.

60. Cosby K, Partovi KS, Crawford JH, Patel RP, Reiter CD, Martyr S, Yang BK, Waclawiw MA, Zalos G, Xu X, Huang KT, Shields H, Kim-Shapiro DB, Schechter AN, Cannon RO, 3rd, Gladwin MT. Nitrite reduction to nitric oxide by deoxyhemoglobin vasodilates the human circulation. Nat Med 9: 1498-505, 2003.

61. Crawford JH, Isbell TS, Huang Z, Shiva S, Chacko BK, Schechter AN, Darley-Usmar VM, Kerby JD, Lang JD, Jr., Kraus D, Ho C, Gladwin MT, Patel RP. Hypoxia, red blood cells, and nitrite regulate NO-dependent hypoxic vasodilation. Blood 107: 56674, 2006. 
62. Crystal GJ, El-Orbany M, Zhou X, Salem MR, Kim SJ. Hemodilution does not alter the coronary vasodilating effects of endogenous or exogenous nitric oxide. Can J Anaesth 55: 507-14, 2008.

63. Crystal GJ, Zhou X, Halim AA, Alam S, El-Orbany M, Salem MR. Nitric oxide does not modulate whole body oxygen consumption in anesthetized dogs. J Appl Physiol 86: 1944-9, 1999.

64. Dai R, Phillips RA, Zhang Y, Khan D, Crasta O, Ahmed SA. Suppression of LPSinduced Interferon-gamma and nitric oxide in splenic lymphocytes by select estrogenregulated microRNAs: a novel mechanism of immune modulation. Blood 112: 45917, 2008.

65. Daut J, Maier-Rudolph W, von Beckerath N, Mehrke G, Gunther K, Goedel-Meinen L. Hypoxic dilation of coronary arteries is mediated by ATP-sensitive potassium channels. Science 247: 1341-4, 1990.

66. Dejam A, Hunter CJ, Schechter AN, Gladwin MT. Emerging role of nitrite in human biology. Blood Cells Mol Dis 32: 423-9, 2004.

67. Devlin C, Greco S, Martelli F, Ivan M. miR-210: More than a silent player in hypoxia. IUBMB Life 63: 94-100, 2011.

68. Di Lisa F, Bernardi P. Mitochondrial function as a determinant of recovery or death in cell response to injury. Mol Cell Biochem 184: 379-91, 1998.

69. Diaz-Ruiz R, Averet N, Araiza D, Pinson B, Uribe-Carvajal S, Devin A, Rigoulet M. Mitochondrial oxidative phosphorylation is regulated by fructose 1,6-bisphosphate. A possible role in Crabtree effect induction? J Biol Chem 283: 26948-55, 2008.

70. Diesen DL, Hess DT, Stamler JS. Hypoxic vasodilation by red blood cells: evidence for an s-nitrosothiol-based signal. Circ Res 103: 545-53, 2008.

71. Dulak J, Jozkowicz A. Regulation of vascular endothelial growth factor synthesis by nitric oxide: facts and controversies. Antioxid Redox Signal 5: 123-32, 2003. 
72. Duranteau J, Chandel NS, Kulisz A, Shao Z, Schumacker PT. Intracellular signaling by reactive oxygen species during hypoxia in cardiomyocytes. J Biol Chem 273: 11619-24, 1998.

73. Dyson A, Bryan NS, Fernandez BO, Garcia-Saura MF, Saijo F, Mongardon N, Rodriguez J, Singer M, Feelisch M. An integrated approach to assessing nitrosoredox balance in systemic inflammation. Free Radic Biol Med, 2011.

74. Ellsworth ML. The red blood cell as an oxygen sensor: what is the evidence? Acta Physiol Scand 168: 551-9, 2000.

75. Ellsworth ML, Ellis CG, Goldman D, Stephenson AH, Dietrich HH, Sprague RS. Erythrocytes: oxygen sensors and modulators of vascular tone. Physiology (Bethesda) 24: 107-16, 2009.

76. Erzurum SC, Ghosh S, Janocha AJ, Xu W, Bauer S, Bryan NS, Tejero J, Hemann C, Hille R, Stuehr DJ, Feelisch M, Beall CM. Higher blood flow and circulating NO products offset high-altitude hypoxia among Tibetans. Proc Natl Acad Sci U S A 104: 17593-8, 2007.

77. Feelisch M, Fernandez BO, Bryan NS, Garcia-Saura MF, Bauer S, Whitlock DR, Ford PC, Janero DR, Rodriguez J, Ashrafian H. Tissue processing of nitrite in hypoxia: an intricate interplay of nitric oxide-generating and -scavenging systems. $J$ Biol Chem 283: 33927-34, 2008.

78. Feelisch M, Rassaf T, Mnaimneh S, Singh N, Bryan NS, Jourd'Heuil D, Kelm M. Concomitant S-, N-, and heme-nitros(yl)ation in biological tissues and fluids: implications for the fate of NO in vivo. FASEB J 16: 1775-85, 2002.

79. Flogel U, Merx MW, Godecke A, Decking UK, Schrader J. Myoglobin: A scavenger of bioactive NO. Proc Natl Acad Sci U S A 98: 735-40, 2001.

80. Fox CJ, Hammerman PS, Thompson CB. Fuel feeds function: energy metabolism and the T-cell response. Nat Rev Immunol 5: 844-52, 2005. 
81. Frost MT, Wang Q, Moncada S, Singer M. Hypoxia accelerates nitric oxidedependent inhibition of mitochondrial complex I in activated macrophages. Am J Physiol Regul Integr Comp Physiol 288: R394-400, 2005.

82. Fukuda R, Zhang H, Kim JW, Shimoda L, Dang CV, Semenza GL. HIF-1 regulates cytochrome oxidase subunits to optimize efficiency of respiration in hypoxic cells. Cell 129: 111-22, 2007.

83. Fukumura D, Gohongi T, Kadambi A, Izumi Y, Ang J, Yun CO, Buerk DG, Huang PL, Jain RK. Predominant role of endothelial nitric oxide synthase in vascular endothelial growth factor-induced angiogenesis and vascular permeability. Proc Natl Acad Sci U S A 98: 2604-9, 2001.

84. Furukawa K, Ohshima N, Tawada-Iwata Y, Shigekawa M. Cyclic GMP stimulates $\mathrm{Na}+/ \mathrm{Ca} 2+$ exchange in vascular smooth muscle cells in primary culture. J Biol Chem 266: 12337-41, 1991 .

85. Galkin A, Abramov AY, Frakich N, Duchen MR, Moncada S. Lack of oxygen deactivates mitochondrial complex I: implications for ischemic injury? J Biol Chem 284: 36055-61, 2009.

86. Gaucher C, Boudier A, Dahboul F, Parent M, Leroy P. S-nitrosation/denitrosation in cardiovascular pathologies: facts and concepts for the rational design of Snitrosothiols. Curr Pharm Des, 2012.

87. Gautier C, van Faassen E, Mikula I, Martasek P, Slama-Schwok A. Endothelial nitric oxide synthase reduces nitrite anions to NO under anoxia. Biochem Biophys Res Commun 341: 816-21, 2006.

88. Giulivi C, Poderoso JJ, Boveris A. Production of nitric oxide by mitochondria. J Biol Chem 273: 11038-43, 1998.

89. Gladwin MT, Kim-Shapiro DB. The functional nitrite reductase activity of the hemeglobins. Blood 112: 2636-47, 2008.

90. Gladwin MT, Shelhamer JH, Schechter AN, Pease-Fye ME, Waclawiw MA, Panza JA, Ognibene FP, Cannon RO, 3rd. Role of circulating nitrite and S- 
nitrosohemoglobin in the regulation of regional blood flow in humans. Proc Natl Acad Sci U S A 97: 11482-7, 2000.

91. Greer SN, Metcalf JL, Wang Y, Ohh M. The updated biology of hypoxia-inducible factor. EMBO J 31: 2448-60, 2012.

92. Gryglewski RJ, Palmer RM, Moncada S. Superoxide anion is involved in the breakdown of endothelium-derived vascular relaxing factor. Nature 320: 454-6, 1986.

93. Guo Z, Shao L, Zheng L, Du Q, Li P, John B, Geller DA. miRNA-939 regulates human inducible nitric oxide synthase posttranscriptional gene expression in human hepatocytes. Proc Natl Acad Sci U S A 109: 5826-31, 2012.

94. Gutierrez G. Cellular energy metabolism during hypoxia. Crit Care Med 19: 619-26, 1991.

95. Guzy RD, Hoyos B, Robin E, Chen H, Liu L, Mansfield KD, Simon MC, Hammerling $\mathrm{U}$, Schumacker PT. Mitochondrial complex III is required for hypoxia-induced ROS production and cellular oxygen sensing. Cell Metab 1: 401-8, 2005.

96. Guzy RD, Schumacker PT. Oxygen sensing by mitochondria at complex III: the paradox of increased reactive oxygen species during hypoxia. Exp Physiol 91: 80719, 2006.

97. Gwathmey TM, Alzayadneh EM, Pendergrass KD, Chappell MC. Novel roles of nuclear angiotensin receptors and signaling mechanisms. Am J Physiol Regul Integr Comp Physiol 302: R518-30, 2012.

98. Hackel DB, Goodale WT, Kleinerman J. Effects of hypoxia on the myocardial metabolism of intact dogs. Circ Res 2: 169-74, 1954.

99. Hagen T, Taylor CT, Lam F, Moncada S. Redistribution of intracellular oxygen in hypoxia by nitric oxide: effect on HIF1alpha. Science 302: 1975-8, 2003.

100. Hakim TS, Sugimori K, Camporesi EM, Anderson G. Half-life of nitric oxide in aqueous solutions with and without haemoglobin. Physiol Meas 17: 267-77, 1996.

101. Haldane JS, Meakins JC, Priestley JG. The respiratory response to anoxaemia. $J$ Physiol 52: 420-32, 1919. 
102. Hall JE. Guyton and Hall textbook of medical physiology Philadelphia, PA: W.B. Saunders Company; 2010.

103. Hardie DG. AMP-activated/SNF1 protein kinases: conserved guardians of cellular energy. Nat Rev Mol Cell Biol 8: 774-85, 2007.

104. Heistad DD, Wheeler RC. Effect of acute hypoxia on vascular responsiveness in man. I. Responsiveness to lower body negative pressure and ice on the forehead. II. Responses to norepinephrine and angiotensin. 3. Effect of hypoxia and hypocapnia. J Clin Invest 49: 1252-65, 1970.

105. Hendgen-Cotta UB, Merx MW, Shiva S, Schmitz J, Becher S, Klare JP, Steinhoff HJ, Goedecke A, Schrader J, Gladwin MT, Kelm M, Rassaf T. Nitrite reductase activity of myoglobin regulates respiration and cellular viability in myocardial ischemiareperfusion injury. Proc Natl Acad Sci U S A 105: 10256-61, 2008.

106. Henze AT, Acker T. Feedback regulators of hypoxia-inducible factors and their role in cancer biology. Cell Cycle 9: 2749-63, 2010.

107. Herold S, Exner M, Nauser T. Kinetic and mechanistic studies of the NO*-mediated oxidation of oxymyoglobin and oxyhemoglobin. Biochemistry 40: 3385-95, 2001.

108. Hess DT, Matsumoto A, Kim SO, Marshall HE, Stamler JS. Protein S-nitrosylation: purview and parameters. Nat Rev Mol Cell Biol 6: 150-66, 2005.

109. Heyes MP, Farber MO, Manfredi F, Robertshaw D, Weinberger M, Fineberg N, Robertson G. Acute effects of hypoxia on renal and endocrine function in normal humans. Am J Physiol 243: R265-70, 1982.

110. Hirsila M, Koivunen P, Gunzler V, Kivirikko KI, Myllyharju J. Characterization of the human prolyl 4-hydroxylases that modify the hypoxia-inducible factor. J Biol Chem 278: 30772-80, 2003.

111. Hochachka PW, Buck LT, Doll CJ, Land SC. Unifying theory of hypoxia tolerance: molecular/metabolic defense and rescue mechanisms for surviving oxygen lack. Proc Natl Acad Sci U S A 93: 9493-8, 1996. 
112. Hochachka PW, Gunga HC, Kirsch K. Our ancestral physiological phenotype: an adaptation for hypoxia tolerance and for endurance performance? Proc Natl Acad Sci U S A 95: 1915-20, 1998.

113. Hochachka PW, Stanley C, Matheson GO, McKenzie DC, Allen PS, Parkhouse WS. Metabolic and work efficiencies during exercise in Andean natives. J Appl Physiol 70: 1720-30, 1991.

114. Ignarro LJ, Cirino G, Casini A, Napoli C. Nitric oxide as a signaling molecule in the vascular system: an overview. J Cardiovasc Pharmacol 34: 879-86, 1999.

115. Ignarro LJ, Fukuto JM, Griscavage JM, Rogers NE, Byrns RE. Oxidation of nitric oxide in aqueous solution to nitrite but not nitrate: comparison with enzymatically formed nitric oxide from L-arginine. Proc Natl Acad Sci U S A 90: 8103-7, 1993.

116. Ingram TE, Pinder AG, Bailey DM, Fraser AG, James PE. Low-dose sodium nitrite vasodilates hypoxic human pulmonary vasculature by a means that is not dependent on a simultaneous elevation in plasma nitrite. Am J Physiol Heart Circ Physiol 298: H331-9, 2010.

117. Isbell TS, Gladwin MT, Patel RP. Hemoglobin oxygen fractional saturation regulates nitrite-dependent vasodilation of aortic ring bioassays. Am J Physiol Heart Circ Physiol 293: H2565-72, 2007.

118. Isbell TS, Sun CW, Wu LC, Teng X, Vitturi DA, Branch BG, Kevil CG, Peng N, Wyss JM, Ambalavanan N, Schwiebert L, Ren J, Pawlik KM, Renfrow MB, Patel RP, Townes TM. SNO-hemoglobin is not essential for red blood cell-dependent hypoxic vasodilation. Nat Med 14: 773-7, 2008.

119. Iwamoto J, Yoshinaga M, Yang SP, Krasney E, Krasney J. Methylene blue inhibits hypoxic cerebral vasodilation in awake sheep. J Appl Physiol 73: 2226-32, 1992.

120. Jekabsone A, Neher JJ, Borutaite V, Brown GC. Nitric oxide from neuronal nitric oxide synthase sensitises neurons to hypoxia-induced death via competitive inhibition of cytochrome oxidase. J Neurochem 103: 346-56, 2007. 
121. Jia L, Bonaventura C, Bonaventura J, Stamler JS. S-nitrosohaemoglobin: a dynamic activity of blood involved in vascular control. Nature 380: 221-6, 1996.

122. Jobgen WS, Fried SK, Fu WJ, Meininger CJ, Wu G. Regulatory role for the argininenitric oxide pathway in metabolism of energy substrates. J Nutr Biochem 17: 571-88, 2006.

123. Johns RA, Linden JM, Peach MJ. Endothelium-dependent relaxation and cyclic GMP accumulation in rabbit pulmonary artery are selectively impaired by moderate hypoxia. Circ Res 65: 1508-15, 1989.

124. Joshi MS, Ferguson TB, Jr., Han TH, Hyduke DR, Liao JC, Rassaf T, Bryan N, Feelisch M, Lancaster JR, Jr. Nitric oxide is consumed, rather than conserved, by reaction with oxyhemoglobin under physiological conditions. Proc Natl Acad Sci U S A 99: 10341-6, 2002.

125. Jung F, Palmer LA, Zhou N, Johns RA. Hypoxic regulation of inducible nitric oxide synthase via hypoxia inducible factor-1 in cardiac myocytes. Circ Res 86: 319-25, 2000.

126. Kaelin WG, Jr., Ratcliffe PJ. Oxygen sensing by metazoans: the central role of the HIF hydroxylase pathway. Mol Cell 30: 393-402, 2008.

127. Kafer ER, Sugioka K. Respiratory and cardiovascular responses to hypoxemia and the effects of anesthesia. Int Anesthesiol Clin 19: 85-122, 1981.

128. Kahn BB, Alquier T, Carling D, Hardie DG. AMP-activated protein kinase: ancient energy gauge provides clues to modern understanding of metabolism. Cell Metab 1: 15-25, 2005.

129. Kawano T, Zoga V, Kimura M, Liang MY, Wu HE, Gemes G, McCallum JB, Kwok WM, Hogan QH, Sarantopoulos CD. Nitric oxide activates ATP-sensitive potassium channels in mammalian sensory neurons: action by direct S-nitrosylation. Mol Pain 5: 12, 2009.

130. Keith B, Johnson RS, Simon MC. HIF1alpha and HIF2alpha: sibling rivalry in hypoxic tumour growth and progression. Nat Rev Cancer 12: 9-22, 2012. 
131. Kelm M. Nitric oxide metabolism and breakdown. Biochim Biophys Acta 1411: 27389, 1999.

132. Kemp PJ. Detecting acute changes in oxygen: will the real sensor please stand up? Exp Physiol 91: 829-34, 2006.

133. Klausen T, Olsen NV, Poulsen TD, Richalet JP, Pedersen BK. Hypoxemia increases serum interleukin-6 in humans. Eur J Appl Physiol Occup Physiol 76: 480-2, 1997.

134. Kleinbongard P, Schulz R, Rassaf T, Lauer T, Dejam A, Jax T, Kumara I, Gharini P, Kabanova S, Ozuyaman B, Schnurch HG, Godecke A, Weber AA, Robenek M, Robenek H, Bloch W, Rosen P, Kelm M. Red blood cells express a functional endothelial nitric oxide synthase. Blood 107: 2943-51, 2006.

135. Knowles RG, Moncada S. Nitric oxide synthases in mammals. Biochem J 298 ( Pt 2): 249-58, 1994.

136. Kojic ZZ, Flogel U, Schrader J, Decking UK. Endothelial NO formation does not control myocardial O2 consumption in mouse heart. Am J Physiol Heart Circ Physiol 285: H392-7, 2003.

137. Kotlo KU, Hesabi B, Danziger RS. Implication of microRNAs in Atrial Natriuretic Peptide- and Nitric Oxide Signaling in Vascular Smooth Muscle Cells. Am J Physiol Cell Physiol, 2011.

138. Kozlov AV, Staniek K, Nohl H. Nitrite reductase activity is a novel function of mammalian mitochondria. FEBS Lett 454: 127-30, 1999.

139. Krotova K, Patel JM, Block ER, Zharikov S. Hypoxic upregulation of arginase II in human lung endothelial cells. Am J Physiol Cell Physiol 299: C1541-8, 2010.

140. Kulshreshtha R, Davuluri RV, Calin GA, Ivan M. A microRNA component of the hypoxic response. Cell Death Differ 15: 667-71, 2008.

141. Kulshreshtha R, Ferracin M, Negrini M, Calin GA, Davuluri RV, Ivan M. Regulation of microRNA expression: the hypoxic component. Cell Cycle 6: 1426-31, 2007. 
142. Lacza Z, Pankotai E, Csordas A, Gero D, Kiss L, Horvath EM, Kollai M, Busija DW, Szabo C. Mitochondrial NO and reactive nitrogen species production: does mtNOS exist? Nitric Oxide 14: 162-8, 2006.

143. Landry DW, Oliver JA. The pathogenesis of vasodilatory shock. N Engl J Med 345: 588-95, 2001.

144. Lauer T, Preik M, Rassaf T, Strauer BE, Deussen A, Feelisch M, Kelm M. Plasma nitrite rather than nitrate reflects regional endothelial nitric oxide synthase activity but lacks intrinsic vasodilator action. Proc Natl Acad Sci U S A 98: 12814-9, 2001.

145. Lehninger A, Nelson D, Cox M. Lehninger Principles of Biochemistry New York: W. H. Freeman; 2008.

146. Leone AM, Palmer RM, Knowles RG, Francis PL, Ashton DS, Moncada S. Constitutive and inducible nitric oxide synthases incorporate molecular oxygen into both nitric oxide and citrulline. J Biol Chem 266: 23790-5, 1991.

147. Levett DZ, Fernandez BO, Riley HL, Martin DS, Mitchell K, Leckstrom CA, Ince C, Whipp BJ, Mythen MG, Montgomery HE, Grocott MP, Feelisch M. The role of nitrogen oxides in human adaptation to hypoxia. Sci. Rep. 1, 2011.

148. Lhuillier F, Parmantier P, Goudable J, Crova P, Delafosse B, Annat G, Cespuglio R, Viale JP. Hepatic ischemia is associated with an increase in liver parenchyma nitric oxide that is in part enzyme-independent. Anesthesiology 98: 373-8, 2003.

149. Li H, Cui H, Kundu TK, Alzawahra W, Zweier JL. Nitric oxide production from nitrite occurs primarily in tissues not in the blood: critical role of xanthine oxidase and aldehyde oxidase. J Biol Chem 283: 17855-63, 2008.

150. Li H, Kundu TK, Zweier JL. Characterization of the magnitude and mechanism of aldehyde oxidase-mediated nitric oxide production from nitrite. J Biol Chem 284: 33850-8, 2009.

151. Li H, Liu X, Cui H, Chen YR, Cardounel AJ, Zweier JL. Characterization of the mechanism of cytochrome P450 reductase-cytochrome P450-mediated nitric oxide and nitrosothiol generation from organic nitrates. J Biol Chem 281: 12546-54, 2006. 
152. Li H, Samouilov A, Liu X, Zweier JL. Characterization of the magnitude and kinetics of xanthine oxidase-catalyzed nitrate reduction: evaluation of its role in nitrite and nitric oxide generation in anoxic tissues. Biochemistry 42: 1150-9, 2003.

153. Li J, Hu X, Selvakumar P, Russell RR, 3rd, Cushman SW, Holman GD, Young LH. Role of the nitric oxide pathway in AMPK-mediated glucose uptake and GLUT4 translocation in heart muscle. Am J Physiol Endocrinol Metab 287: E834-41, 2004.

154. Liao JC, Hein TW, Vaughn MW, Huang KT, Kuo L. Intravascular flow decreases erythrocyte consumption of nitric oxide. Proc Natl Acad Sci U S A 96: 8757-61, 1999.

155. Liao JK, Zulueta JJ, Yu FS, Peng HB, Cote CG, Hassoun PM. Regulation of bovine endothelial constitutive nitric oxide synthase by oxygen. J Clin Invest 96: 2661-6, 1995.

156. Licker M, Schweizer A, Hohn L, Morel DR. Haemodynamic and metabolic changes induced by repeated episodes of hypoxia in pigs. Acta Anaesthesiol Scand 42: 95765, 1998.

157. Lima B, Forrester MT, Hess DT, Stamler JS. S-nitrosylation in cardiovascular signaling. Circ Res 106: 633-46, 2010.

158. Liu X, Miller MJ, Joshi MS, Sadowska-Krowicka H, Clark DA, Lancaster JR, Jr. Diffusion-limited reaction of free nitric oxide with erythrocytes. J Biol Chem 273: 18709-13, 1998.

159. Liu X, Yan Q, Baskerville KL, Zweier JL. Estimation of nitric oxide concentration in blood for different rates of generation. Evidence that intravascular nitric oxide levels are too low to exert physiological effects. J Biol Chem 282: 8831-6, 2007.

160. Loboda A, Jozkowicz A, Dulak J. HIF-1 and HIF-2 transcription factors--similar but not identical. Mol Cells 29: 435-42, 2010.

161. Loboda A, Jozkowicz A, Dulak J. HIF-1 versus HIF-2--is one more important than the other? Vascul Pharmacol 56: 245-51, 2012.

162. Lohman AW, Billaud M, Isakson BE. Mechanisms of ATP release and signalling in the blood vessel wall. Cardiovasc Res 95: 269-80, 2012. 
163. Louis CA, Reichner JS, Henry WL, Jr., Mastrofrancesco B, Gotoh T, Mori M, Albina JE. Distinct arginase isoforms expressed in primary and transformed macrophages: regulation by oxygen tension. Am J Physiol 274: R775-82, 1998.

164. Lundberg JO, Gladwin MT, Ahluwalia A, Benjamin N, Bryan NS, Butler A, Cabrales P, Fago A, Feelisch M, Ford PC, Freeman BA, Frenneaux M, Friedman J, Kelm M, Kevil CG, Kim-Shapiro DB, Kozlov AV, Lancaster JR, Jr., Lefer DJ, McColl K, McCurry K, Patel RP, Petersson J, Rassaf T, Reutov VP, Richter-Addo GB, Schechter A, Shiva S, Tsuchiya K, van Faassen EE, Webb AJ, Zuckerbraun BS, Zweier JL, Weitzberg E. Nitrate and nitrite in biology, nutrition and therapeutics. Nat Chem Biol 5: 865-9, 2009.

165. Lundberg JO, Weitzberg E, Cole JA, Benjamin N. Nitrate, bacteria and human health. Nat Rev Microbiol 2: 593-602, 2004.

166. Lundberg JO, Weitzberg E, Gladwin MT. The nitrate-nitrite-nitric oxide pathway in physiology and therapeutics. Nat Rev Drug Discov 7: 156-67, 2008.

167. Luss H, Li RK, Shapiro RA, Tzeng E, McGowan FX, Yoneyama T, Hatakeyama K, Geller DA, Mickle DA, Simmons RL, Billiar TR. Dedifferentiated human ventricular cardiac myocytes express inducible nitric oxide synthase mRNA but not protein in response to IL-1, TNF, IFNgamma, and LPS. J Mol Cell Cardiol 29: 1153-65, 1997.

168. Maciver NJ, Jacobs SR, Wieman HL, Wofford JA, Coloff JL, Rathmell JC. Glucose metabolism in lymphocytes is a regulated process with significant effects on immune cell function and survival. J Leukoc Biol 84: 949-57, 2008.

169. Majmundar AJ, Wong WJ, Simon MC. Hypoxia-inducible factors and the response to hypoxic stress. Mol Cell 40: 294-309, 2010.

170. Mander P, Borutaite V, Moncada S, Brown GC. Nitric oxide from inflammatoryactivated glia synergizes with hypoxia to induce neuronal death. J Neurosci Res 79: 208-15, 2005. 
171. Melikian N, Seddon MD, Casadei B, Chowienczyk PJ, Shah AM. Neuronal nitric oxide synthase and human vascular regulation. Trends Cardiovasc Med 19: 256-62, 2009.

172. Melillo G, Musso T, Sica A, Taylor LS, Cox GW, Varesio L. A hypoxia-responsive element mediates a novel pathway of activation of the inducible nitric oxide synthase promoter. J Exp Med 182: 1683-93, 1995.

173. Messina EJ, Sun D, Koller A, Wolin MS, Kaley G. Role of endothelium-derived prostaglandins in hypoxia-elicited arteriolar dilation in rat skeletal muscle. Circ Res 71: 790-6, 1992.

174. Millar TM, Stevens CR, Benjamin N, Eisenthal R, Harrison R, Blake DR. Xanthine oxidoreductase catalyses the reduction of nitrates and nitrite to nitric oxide under hypoxic conditions. FEBS Lett 427: 225-8, 1998.

175. Millatt LJ, Whitley GS, Li D, Leiper JM, Siragy HM, Carey RM, Johns RA. Evidence for dysregulation of dimethylarginine dimethylaminohydrolase I in chronic hypoxiainduced pulmonary hypertension. Circulation 108: 1493-8, 2003.

176. Modin A, Bjorne H, Herulf M, Alving K, Weitzberg E, Lundberg JO. Nitrite-derived nitric oxide: a possible mediator of 'acidic-metabolic' vasodilation. Acta Physiol Scand 171: 9-16, 2001.

177. Moncada S, Higgs A. The L-arginine-nitric oxide pathway. N Engl J Med 329: 200212, 1993.

178. Munk VC, de Miguel LS, Humar R, Kiefer FN, Butz N, Battegay E. iNOS is required for in vitro angiogenesis of hypoxic mouse hearts. Semin Cardiol 12: 21-26, 2006.

179. Murphy ME, Brayden JE. Nitric oxide hyperpolarizes rabbit mesenteric arteries via ATP-sensitive potassium channels. J Physiol 486 ( Pt 1): 47-58, 1995.

180. Nagasaka Y, Fernandez BO, Garcia-Saura MF, Petersen B, Ichinose F, Bloch KD, Feelisch M, Zapol WM. Brief periods of nitric oxide inhalation protect against myocardial ischemia-reperfusion injury. Anesthesiology 109: 675-82, 2008. 
181. Olearczyk JJ, Ellsworth ML, Stephenson AH, Lonigro AJ, Sprague RS. Nitric oxide inhibits ATP release from erythrocytes. J Pharmacol Exp Ther 309: 1079-84, 2004.

182. Oliver MF, Opie LH. Effects of glucose and fatty acids on myocardial ischaemia and arrhythmias. Lancet 343: 155-8, 1994.

183. Olsen NV. Effect of hypoxaemia on water and sodium homeostatic hormones and renal function. Acta Anaesthesiol Scand Suppl 107: 165-70, 1995.

184. Opie LH. Myocardial ischemia--metabolic pathways and implications of increased glycolysis. Cardiovasc Drugs Ther 4 Suppl 4: 777-90, 1990.

185. Ormerod JO, Ashrafian H, Maher AR, Arif S, Steeples V, Born GV, Egginton S, Feelisch M, Watkins H, Frenneaux MP. The role of vascular myoglobin in nitritemediated blood vessel relaxation. Cardiovasc Res 89: 560-5, 2011.

186. Palacios-Callender M, Hollis V, Mitchison M, Frakich N, Unitt D, Moncada S. Cytochrome c oxidase regulates endogenous nitric oxide availability in respiring cells: a possible explanation for hypoxic vasodilation. Proc Natl Acad Sci U S A 104: 18508-13, 2007.

187. Palmer RM, Ferrige AG, Moncada S. Nitric oxide release accounts for the biological activity of endothelium-derived relaxing factor. Nature 327: 524-6, 1987.

188. Papandreou I, Cairns RA, Fontana L, Lim AL, Denko NC. HIF-1 mediates adaptation to hypoxia by actively downregulating mitochondrial oxygen consumption. Cell Metab 3: 187-97, 2006.

189. Park CS, Park R, Krishna G. Constitutive expression and structural diversity of inducible isoform of nitric oxide synthase in human tissues. Life Sci 59: 219-25, 1996.

190. Park KH, Rubin LE, Gross SS, Levi R. Nitric oxide is a mediator of hypoxic coronary vasodilatation. Relation to adenosine and cyclooxygenase-derived metabolites. Circ Res 71: 992-1001, 1992.

191. Pawloski JR, Hess DT, Stamler JS. Export by red blood cells of nitric oxide bioactivity. Nature 409: 622-6, 2001. 
192. Pearce LL, Kanai AJ, Birder LA, Pitt BR, Peterson J. The catabolic fate of nitric oxide: the nitric oxide oxidase and peroxynitrite reductase activities of cytochrome oxidase. J Biol Chem 277: 13556-62, 2002.

193. Petersson J, Carlstrom M, Schreiber O, Phillipson M, Christoffersson G, Jagare A, Roos S, Jansson EA, Persson AE, Lundberg JO, Holm L. Gastroprotective and blood pressure lowering effects of dietary nitrate are abolished by an antiseptic mouthwash. Free Radic Biol Med 46: 1068-75, 2009.

194. Phillips BA, McConnell JW, Smith MD. The effects of hypoxemia on cardiac output. A dose-response curve. Chest 93: 471-5, 1988.

195. Pinder AG, Pittaway E, Morris K, James PE. Nitrite directly vasodilates hypoxic vasculature via nitric oxide-dependent and -independent pathways. Br J Pharmacol 157: 1523-30, 2009.

196. Pohl U, Busse R. Hypoxia stimulates release of endothelium-derived relaxant factor. Am J Physiol 256: H1595-600, 1989.

197. Prime TA, Blaikie FH, Evans C, Nadtochiy SM, James AM, Dahm CC, Vitturi DA, Patel RP, Hiley CR, Abakumova I, Requejo R, Chouchani ET, Hurd TR, Garvey JF, Taylor CT, Brookes PS, Smith RA, Murphy MP. A mitochondria-targeted Snitrosothiol modulates respiration, nitrosates thiols, and protects against ischemiareperfusion injury. Proc Natl Acad Sci U S A 106: 10764-9, 2009.

198. Rassaf T, Bryan NS, Maloney RE, Specian V, Kelm M, Kalyanaraman B, Rodriguez J, Feelisch M. NO adducts in mammalian red blood cells: too much or too little? Nat Med 9: 481-2; author reply 482-3, 2003.

199. Rassaf T, Flogel U, Drexhage C, Hendgen-Cotta U, Kelm M, Schrader J. Nitrite reductase function of deoxymyoglobin: oxygen sensor and regulator of cardiac energetics and function. Circ Res 100: 1749-54, 2007.

200. Rengasamy A, Johns RA. Characterization of endothelium-derived relaxing factor/nitric oxide synthase from bovine cerebellum and mechanism of modulation by high and low oxygen tensions. J Pharmacol Exp Ther 259: 310-6, 1991. 
201. Rengasamy A, Johns RA. Determination of Km for oxygen of nitric oxide synthase isoforms. J Pharmacol Exp Ther 276: 30-3, 1996.

202. Rixen D, Siegel JH. Bench-to-bedside review: oxygen debt and its metabolic correlates as quantifiers of the severity of hemorrhagic and post-traumatic shock. Crit Care 9: 441-53, 2005.

203. Rodriguez J, Maloney RE, Rassaf T, Bryan NS, Feelisch M. Chemical nature of nitric oxide storage forms in rat vascular tissue. Proc Natl Acad Sci U S A 100: 336-41, 2003.

204. Rolfe DF, Brown GC. Cellular energy utilization and molecular origin of standard metabolic rate in mammals. Physiol Rev 77: 731-58, 1997.

205. Rong Z, Banaji M, Moroz T, Cooper CE. Can mitochondrial cytochrome oxidase mediate hypoxic vasodilation via nitric oxide metabolism? Adv Exp Med Biol 765: 231-8, 2013.

206. Rowell LB, Blackmon JR. Human cardiovascular adjustments to acute hypoxaemia. Clin Physiol 7: 349-76, 1987.

207. Rowell LB, Blackmon JR. Hypotension induced by central hypovolaemia and hypoxaemia. Clin Physiol 9: 269-77, 1989.

208. Roy CS, Brown JG. The Blood-Pressure and its Variations in the Arterioles, Capillaries and Smaller Veins. J Physiol 2: 323-446, 1880.

209. Salloum FN, Yin C, Kukreja RC. Role of microRNAs in cardiac preconditioning. $J$ Cardiovasc Pharmacol 56: 581-8, 2010.

210. Sambandam N, Lopaschuk GD. AMP-activated protein kinase (AMPK) control of fatty acid and glucose metabolism in the ischemic heart. Prog Lipid Res 42: 238-56, 2003.

211. Schumacker PT. Hypoxia, anoxia, and $\mathrm{O} 2$ sensing: the search continues. Am J Physiol Lung Cell Mol Physiol 283: L918-21, 2002.

212. Schumacker PT, Cain SM. The concept of a critical oxygen delivery. Intensive Care Med 13: 223-9, 1987. 
213. Schweizer M, Richter $\mathrm{C}$. Nitric oxide potently and reversibly deenergizes mitochondria at low oxygen tension. Biochem Biophys Res Commun 204: 169-75, 1994.

214. Semenza GL. HIF-1: mediator of physiological and pathophysiological responses to hypoxia. J Appl Physiol 88: 1474-80, 2000.

215. Semenza GL. Oxygen-dependent regulation of mitochondrial respiration by hypoxiainducible factor 1. Biochem J 405: 1-9, 2007.

216. Sessa WC. eNOS at a glance. J Cell Sci 117: 2427-9, 2004.

217. Shen W, Xu X, Ochoa M, Zhao G, Wolin MS, Hintze TH. Role of nitric oxide in the regulation of oxygen consumption in conscious dogs. Circ Res 75: 1086-95, 1994.

218. Shiva S, Brookes PS, Patel RP, Anderson PG, Darley-Usmar VM. Nitric oxide partitioning into mitochondrial membranes and the control of respiration at cytochrome c oxidase. Proc Natl Acad Sci U S A 98: 7212-7, 2001.

219. Shiva S, Oh JY, Landar AL, Ulasova E, Venkatraman A, Bailey SM, Darley-Usmar VM. Nitroxia: the pathological consequence of dysfunction in the nitric oxidecytochrome c oxidase signaling pathway. Free Radic Biol Med 38: 297-306, 2005.

220. Shiva S, Wang X, Ringwood LA, Xu X, Yuditskaya S, Annavajjhala V, Miyajima H, Hogg N, Harris ZL, Gladwin MT. Ceruloplasmin is a NO oxidase and nitrite synthase that determines endocrine NO homeostasis. Nat Chem Biol 2: 486-93, 2006.

221. Sonveaux P, Lobysheva, II, Feron O, McMahon TJ. Transport and peripheral bioactivities of nitrogen oxides carried by red blood cell hemoglobin: role in oxygen delivery. Physiology (Bethesda) 22: 97-112, 2007.

222. Sprague B, Chesler NC, Magness RR. Shear stress regulation of nitric oxide production in uterine and placental artery endothelial cells: experimental studies and hemodynamic models of shear stresses on endothelial cells. Int J Dev Biol 54: 331-9, 2010. 
223. Srinivas V, Leshchinsky I, Sang N, King MP, Minchenko A, Caro J. Oxygen sensing and HIF-1 activation does not require an active mitochondrial respiratory chain electron-transfer pathway. J Biol Chem 276: 21995-8, 2001.

224. Stamler JS, Jaraki O, Osborne J, Simon DI, Keaney J, Vita J, Singel D, Valeri CR, Loscalzo J. Nitric oxide circulates in mammalian plasma primarily as an S-nitroso adduct of serum albumin. Proc Natl Acad Sci U S A 89: 7674-7, 1992.

225. Stamler JS, Jia L, Eu JP, McMahon TJ, Demchenko IT, Bonaventura J, Gernert K, Piantadosi CA. Blood flow regulation by S-nitrosohemoglobin in the physiological oxygen gradient. Science 276: 2034-7, 1997.

226. Stamler JS, Simon DI, Osborne JA, Mullins ME, Jaraki O, Michel T, Singel DJ, Loscalzo J. S-nitrosylation of proteins with nitric oxide: synthesis and characterization of biologically active compounds. Proc Natl Acad Sci U S A 89: 444-8, 1992.

227. Sydow K, Munzel T. ADMA and oxidative stress. Atheroscler Supp/ 4: 41-51, 2003.

228. Szabo C, Ischiropoulos H, Radi R. Peroxynitrite: biochemistry, pathophysiology and development of therapeutics. Nat Rev Drug Discov 6: 662-80, 2007.

229. Takeda N, O'Dea EL, Doedens A, Kim JW, Weidemann A, Stockmann C, Asagiri M, Simon MC, Hoffmann A, Johnson RS. Differential activation and antagonistic function of HIF-\{alpha\} isoforms in macrophages are essential for NO homeostasis. Genes Dev 24: 491-501, 2010.

230. Taylor CT, Moncada S. Nitric oxide, cytochrome C oxidase, and the cellular response to hypoxia. Arterioscler Thromb Vasc Biol 30: 643-7, 2010.

231. Taylor CT, Pouyssegur J. Oxygen, hypoxia, and stress. Ann N Y Acad Sci 1113: 8794, 2007.

232. Trochu JN, Bouhour JB, Kaley G, Hintze TH. Role of endothelium-derived nitric oxide in the regulation of cardiac oxygen metabolism: implications in health and disease. Circ Res 87: 1108-17, 2000.

233. Tsai AG, Johnson PC, Intaglietta M. Oxygen gradients in the microcirculation. Physiol Rev 83: 933-63, 2003. 
234. Unitt DC, Hollis VS, Palacios-Callender M, Frakich N, Moncada S. Inactivation of nitric oxide by cytochrome c oxidase under steady-state oxygen conditions. Biochim Biophys Acta 1797: 371-7, 2010.

235. Vallance P, Moncada S. Role of endogenous nitric oxide in septic shock. New Horiz 1: 77-86, 1993.

236. Van Mil AH, Spilt A, Van Buchem MA, Bollen EL, Teppema L, Westendorp RG, Blauw GJ. Nitric oxide mediates hypoxia-induced cerebral vasodilation in humans. $J$ Appl Physiol 92: 962-6, 2002.

237. Vanin AF. Dinitrosyl iron complexes with thiolate ligands: physico-chemistry, biochemistry and physiology. Nitric Oxide 21: 1-13, 2009.

238. Vanin AF, Bevers LM, Slama-Schwok A, van Faassen EE. Nitric oxide synthase reduces nitrite to NO under anoxia. Cell Mol Life Sci 64: 96-103, 2007.

239. Vasquez-Vivar J, Kalyanaraman B, Martasek P, Hogg N, Masters BS, Karoui H, Tordo P, Pritchard KA, Jr. Superoxide generation by endothelial nitric oxide synthase: the influence of cofactors. Proc Natl Acad Sci U S A 95: 9220-5, 1998.

240. Webb AJ, Milsom AB, Rathod KS, Chu WL, Qureshi S, Lovell MJ, Lecomte FM, Perrett D, Raimondo C, Khoshbin E, Ahmed Z, Uppal R, Benjamin N, Hobbs AJ, Ahluwalia A. Mechanisms underlying erythrocyte and endothelial nitrite reduction to nitric oxide in hypoxia: role for xanthine oxidoreductase and endothelial nitric oxide synthase. Circ Res 103: 957-64, 2008.

241. Webb AJ, Patel N, Loukogeorgakis S, Okorie M, Aboud Z, Misra S, Rashid R, Miall P, Deanfield J, Benjamin N, MacAllister R, Hobbs AJ, Ahluwalia A. Acute blood pressure lowering, vasoprotective, and antiplatelet properties of dietary nitrate via bioconversion to nitrite. Hypertension 51: 784-90, 2008.

242. Weber M, Baker MB, Moore JP, Searles CD. MiR-21 is induced in endothelial cells by shear stress and modulates apoptosis and eNOS activity. Biochem Biophys Res Commun 393: 643-8, 2010. 
243. Welch G, Loscalzo J. Nitric oxide and the cardiovascular system. J Card Surg 9: 361$71,1994$.

244. Wheaton WW, Chandel NS. Hypoxia. 2. Hypoxia regulates cellular metabolism. Am J Physiol Cell Physiol 300: C385-93, 2011.

245. Whorton AR, Simonds DB, Piantadosi CA. Regulation of nitric oxide synthesis by oxygen in vascular endothelial cells. Am J Physiol 272: L1161-6, 1997.

246. Wu G, Morris SM, Jr. Arginine metabolism: nitric oxide and beyond. Biochem J 336 ( Pt 1): 1-17, 1998.

247. Xia Y, Tsai AL, Berka V, Zweier JL. Superoxide generation from endothelial nitricoxide synthase. A Ca2+/calmodulin-dependent and tetrahydrobiopterin regulatory process. J Biol Chem 273: 25804-8, 1998.

248. Yin C, Salloum FN, Kukreja RC. A novel role of microRNA in late preconditioning: upregulation of endothelial nitric oxide synthase and heat shock protein 70. Circ Res 104: 572-5, 2009.

249. Zhan J, Nakao A, Sugimoto R, Dhupar R, Wang Y, Wang Z, Billiar TR, McCurry KR. Orally administered nitrite attenuates cardiac allograft rejection in rats. Surgery 146: 155-65, 2009.

250. Zulueta JJ, Sawhney R, Kayyali U, Fogel M, Donaldson C, Huang H, Lanzillo JJ, Hassoun PM. Modulation of inducible nitric oxide synthase by hypoxia in pulmonary artery endothelial cells. Am J Respir Cell Mol Biol 26: 22-30, 2002.

251. Zweier JL, Wang P, Samouilov A, Kuppusamy P. Enzyme-independent formation of nitric oxide in biological tissues. Nat Med 1: 804-9, 1995. 


\section{Figures and figure legends}

\section{Figure 1. Oxygen supply-demand relationship.}

The relationship between oxygen delivery to cells and oxygen consumption is non-linear. Initial reduction in the amount of oxygen delivered are compensated by a series of adaptive mechanisms. If delivery is reduced further, a critical point is reached $\left(\mathrm{DO}_{2}\right.$ crit) below which tissue extraction cannot increase any further, leading to a fall in consumption. Several complementary macro- and microcirculatory mechanisms act to prevent the onset of tissue hypoxia in the face of a reduced delivery, and many of them are mediated by nitric oxide.

\section{Figure 2. Metabolic pathways for arginine.}

Four major metabolic pathways for arginine exist: first, arginine is degraded to urea and ornithine by isoforms of the enzyme arginase. A large part of arginine is used for protein synthesis, and arginine is also involved in the biosynthesis of creatine. Another metabolic pathway of arginine is the synthesis of nitric oxide (NO) by endothelial, neuronal or inducible isoforms of the enzyme NO synthase (respectively, eNOS, nNOS and iNOS) with concomitant formation of citrulline. The NO synthesis reaction requires the presence of two oxygen molecules plus NADPH as coenzymes/cofactors, and proceeds with two steps, a first one in which the intermediate $\mathrm{N}(\mathrm{G})$-hydroxy-L-arginine (N-OH-L-Arg) is formed, and a second one in which NO and citrulline are formed as products.

\section{Figure 3. Multiple pathways of NO synthesis.}

Nitric oxide (NO) synthesis occurs in blood and tissues through the classical L-arginine-NO pathway, where the semi-essential amino acid L-arginine is metabolized to NO and Lcitrulline by a family of nitric oxide synthases (NOS) that use oxygen as co-factor. 
Endogenously-formed or dietary-derived nitrite in blood and tissues may be reduced to NO. Dedicated nitrite reductases are present in bacteria, but are lacking in humans. Nonetheless, certain mammalian enzymes under hypoxic conditions may show some nitrite reductase activity beyond their normal physiologic function, such as proteins from the heme-globin family or from pterin-based molybdenum enzymes. S-nitrosothiols (RSNO) are other circulating reservoirs and carriers of potential nitric oxide bioactivity. Their concentrations vary in different pathophysiologic states, and under hypoxic conditions they may be activated to release NO from their thiol (-SH) group. The most studied of such storage pool is hemoglobin $(\mathrm{Hb})$ : a cysteine residue on the $\beta$-chain may react with NO to form a nitrosoadduct $(\mathrm{SNO}-\mathrm{Hb})$ that, under hypoxic conditions releases NO bioactivity. Traditionally considered as inert oxidative end-products, dietary nitrate $\left(\mathrm{NO}_{3}{ }^{-}\right)$and nitrite $\left(\mathrm{NO}_{2}{ }^{-}\right)$contribute to NO homeostasis through the gastroenteric "nitrate-nitrite-nitric oxide pathway". Once absorbed from the diet, a significant part of plasma $\mathrm{NO}_{3}{ }^{-}$is concentrated in the saliva. Bacteria within the oral cavity then reduce it to nitrite. Nitrite-rich saliva is swallowed, and within the acidic milieu of the gastric lumen $\mathrm{NO}_{2}{ }^{-}$is rapidly converted to $\mathrm{NO}$.

Figure 4. Enzymes with putative nitrite-reductase activity.

Dedicated nitrite reductases are present in bacteria, but are lacking in humans. Nonetheless, certain mammalian enzymes show some nitrite reductase activity beyond their normal physiologic function. As an alternative to non-enzymatic reduction, proteins from the hemeglobin family (such as deoxygenated haemoglobin $-\mathrm{HHb}$, and myoglobin $-\mathrm{HMb}$, the mitochondrial cytochrome bc1 complex - CIII, cytochrome c oxidase - $\mathrm{CcO}$, and cytochrome c - CytC, as well as aldehyde dehydrogenase - ALDH2, the endothelial isoform of NOS eNOS, and soluble guanylate cyclase - sGC) or from pterin-based molybdenum enzymes ( such as xanthyne oxidoreductase - XOR, sulphide oxidase - SO and aldehyde oxidase - 
AO) may all catalyze the $\mathrm{NO}_{2}$-reductase reaction to $\mathrm{NO}$, expecially under hypoxic conditions.

Figure 5. Pathways of NO metabolism in normoxic conditions.

$\mathrm{NO}$ rapidly reacts with molecular oxygen $\left(\mathrm{O}_{2}\right)$ to form nitrogen dioxide $\left(\mathrm{NO}_{2}\right)$. If $\mathrm{NO}$ is present at low concentration, the $\mathrm{NO}_{2}$ reacts with water to form equal amounts of nitrite and nitrate. At higher $\mathrm{NO}$ concentrations, $\mathrm{NO}_{2}$ reacts with another $\mathrm{NO}$ molecule to form dinitrogen trioxide $\left(\mathrm{N}_{2} \mathrm{O}_{3}\right)$, which hydrolyses to form nitrite $\left(\mathrm{NO}_{2}{ }^{-}\right)$, or may dimerize to form dinitrogen tetraoxide $\left(\mathrm{N}_{2} \mathrm{O}_{4}\right)$. In plasma, the principal fate of $\mathrm{NO}$ is formation of $\mathrm{NO}_{2}^{-}$, although the exact reaction is unclear (autoxidation, reaction with ceruloplasmin, or oxidation by the mitochondrial cytochrome c oxidase $-\mathrm{CcO}$ ). In whole blood NO reacts with oxygenated hemoglobin $(\mathrm{oxyHb})$ to form nitrate $\left(\mathrm{NO}_{3}{ }^{-}\right)$with concomitant formation of methemoglobin (MetHb). A similar reaction with oxymyoglobin (oxyMb) happens in tissues. NO can also react with superoxide $\left(\mathrm{O}_{2}{ }^{--}\right)$to produce peroxynitrite (ONOO$)^{-}$; the latter may directly trigger oxidation or nitration reactions with various cellular targets, and is eventually converted into nitrate or $\mathrm{NO}_{2}$. Highly reactive $\mathrm{NO}$ by-products ("reactive nitrogen oxide species", i.e. ONOO , $\mathrm{NO}_{2}, \mathrm{~N}_{2} \mathrm{O}_{3}, \mathrm{~N}_{2} \mathrm{O}_{4}$ ), possibly through the formation of nitrosonium equivalents $\left(\mathrm{NO}^{+}\right.$), can react with protein thiol (-SH) groups to form S-nitrosothiols (RSNOs), or with amines to generate $\mathrm{N}$-nitrosamines (RNNOs). NO can also directly react with metals ( $\mathrm{Me}^{\mathrm{x}}$ ) to give metal nitrosyls (Me ${ }^{x} \mathrm{NO}$ ). In addition to nitrosation, RSNOs may also be produced by oxidative nitrosylation.

Figure 6. Effects of increased NO levels during hypoxia in the balancing of oxygen supply and demand.

Left panel (A). Metabolic and contractile state of an ideal cell during normoxic conditions. ATP supply is maintained through mitochondrial and cytoplasmic reactions. Glucose (Gluc) 
is transported from the interstitium via GLUT carriers. The vast majority of pyruvate, the endproduct of glucose breakdown, enters the mitochondria after oxidation by the enzyme pyruvate dehydrogenase (PDH). Here, it is completely oxidized with reactions coupled to the synthesis of ATP. Oxygen $\left(\mathrm{O}_{2}\right)$ is crucially required as the terminal electron acceptor of the respiratory chain, Cytochrome c Oxidase $(\mathrm{CcO})$. A small part of the pyruvate is reduced to lactate by lactate dehydrogenase (LDH). In conditions of excess of substrate availability, glucose is stored as glycogen. The contractile state of the cell is maintained through cycling of myosin from a phosphorylated to a dephosphorylated state, via the enzymes myosin light chain kinase and phosphatase, respectively (MLCK and MLKP).

Right panel (B). Adaptive modifications of metabolism and contractile state during hypoxia. The increased levels of exogenous or endogenously formed nitric oxide (NO) during hypoxia contribute to the adaptation to the energy supply-demand mismatch. NO reduces mitochondrial metabolic demand by competing with $\mathrm{O}_{2}$ at $\mathrm{CcO}$. It also limits energyconsuming anabolic processes such as glycogen synthesis and induces energy-producing catabolic pathways via the increased expression and activity of GLUT transporters, and of enzymes involved in glycogenolysis and glycolysis, while PDH activity is inhibited. The net effect is a shunting of pyruvate away from mitochondria and an increase in glucose availability and glycolytic flux. NO also activates the enzyme soluble guanylate cyclase (sGC), leading to increased synthesis of cyclic GMP (cGMP). This, in turn, modulates MLCK and MLCP activities, resulting in less phosphorylation of myosin and, eventually, vasorelaxation. NO can also cause vasodilation via cGMP-mediated opening of calciumsensitive $\left(\mathrm{K}_{\mathrm{Ca}}\right)$ and ATP-sensitive $\left(\mathrm{K}_{\mathrm{ATP}}\right)$ potassium channels. When these ion channels open, the outward efflux of $\mathrm{K}^{+}$hyperpolarizes the plasma membrane, reducing vascular tone. NO may also activate those ion channels in a cGMP-independent manner through direct Snitrosylation of cysteine $(\mathrm{SH})$ residues. Eventually, $\mathrm{NO}$ regulates the intracellular free $\mathrm{Ca}^{2+}$ concentration, either via a cGMP-dependent inhibition of calcium influx through L-type $\mathrm{Ca}^{2+}$ channels (LTC), and/or via an increased $\mathrm{Ca}^{2+}$ removal from the cytoplasm. The latter may 
occur by accelerating the $\mathrm{Na}^{+} / \mathrm{Ca}^{2+}$ exchanger (SCE), or increasing the sequestration into intracellular stores via the sarcoplasmic/endoplasmic reticulum (SER). The net effects of an increase in NO levels are reduced consumption of oxygen, increased glycolytic ATP production, and vasodilation that increases the supply of oxygen and nutrients. Solid arrows indicate pathways induced by NO; dashed arrows indicate inhibition.

Figure 7. Effects of hypoxia on NO metabolic pathways

Possible mechanisms of increased NO levels under hypoxic conditions include: 1) increased production by NOS; 2) increased release from storage forms such as RSNO; 3) increased reduction from nitrite; 4) reduced metabolism by $\mathrm{CcO}$. 


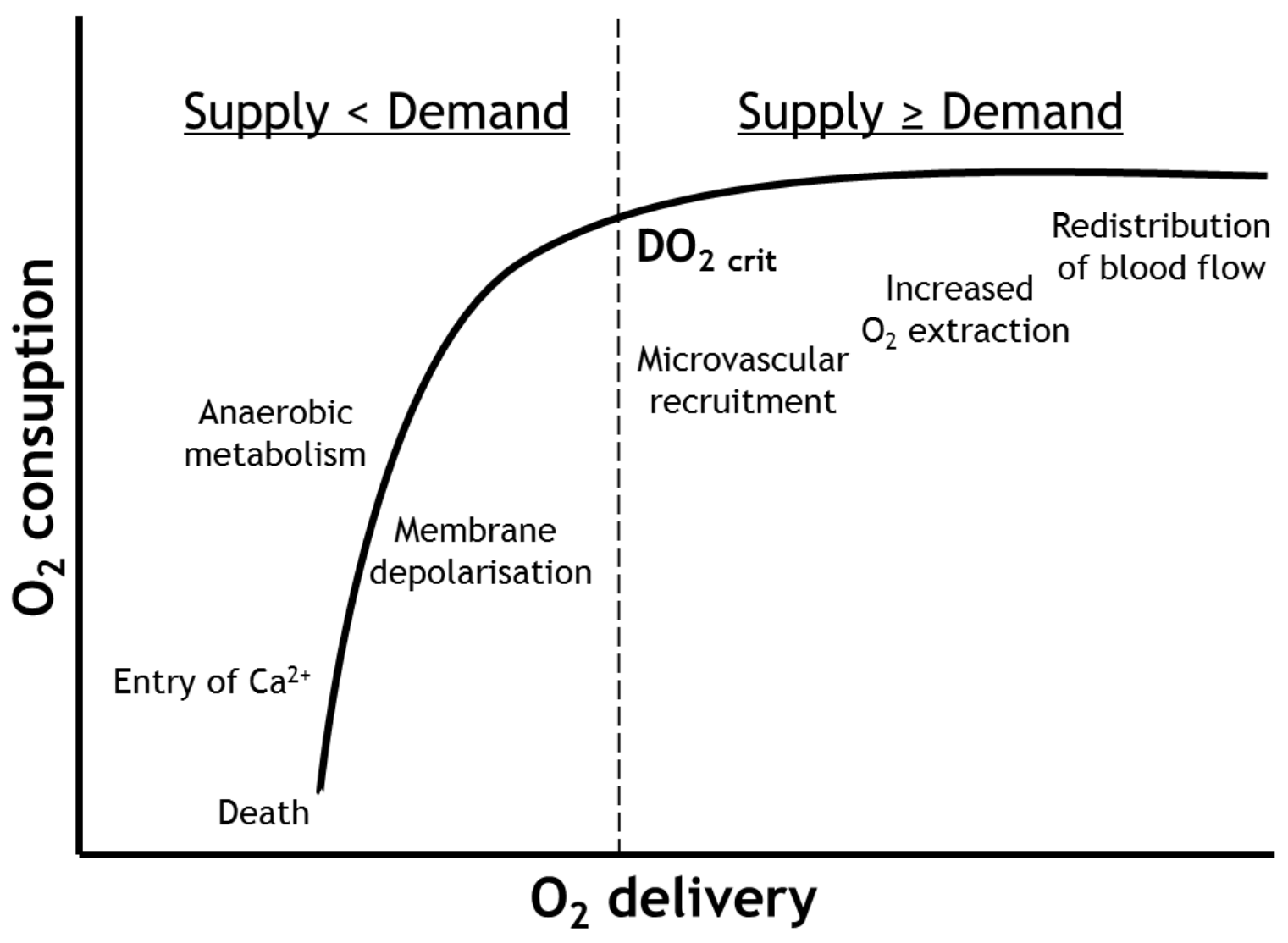




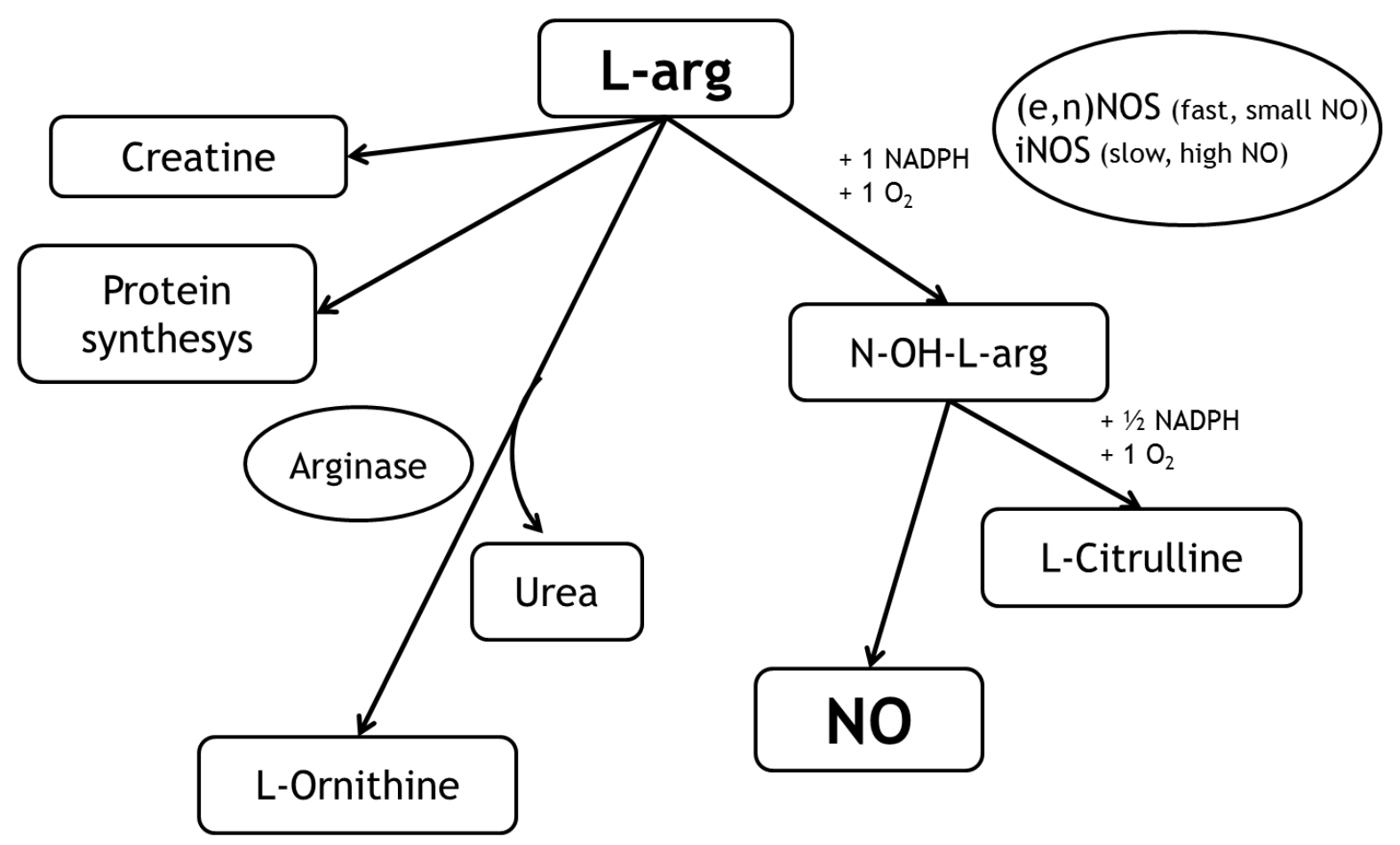




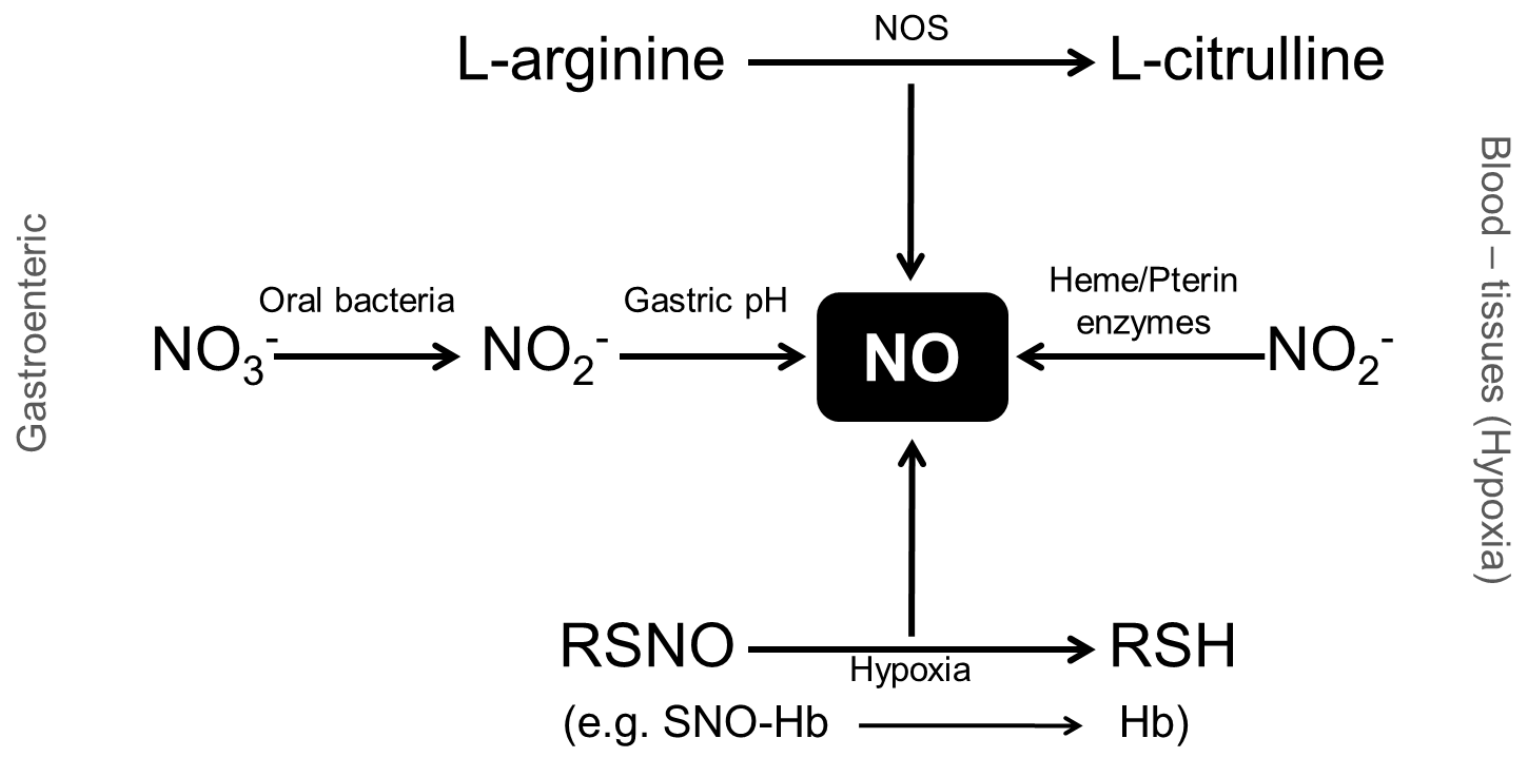

Blood (Hypoxia) 


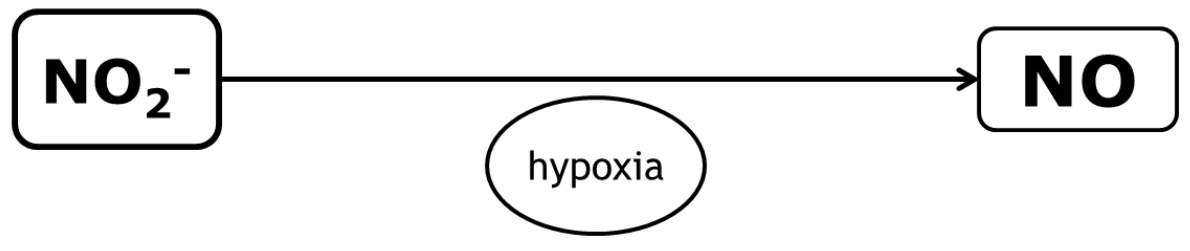

Heme-based enzymes Pterin-based enzymes

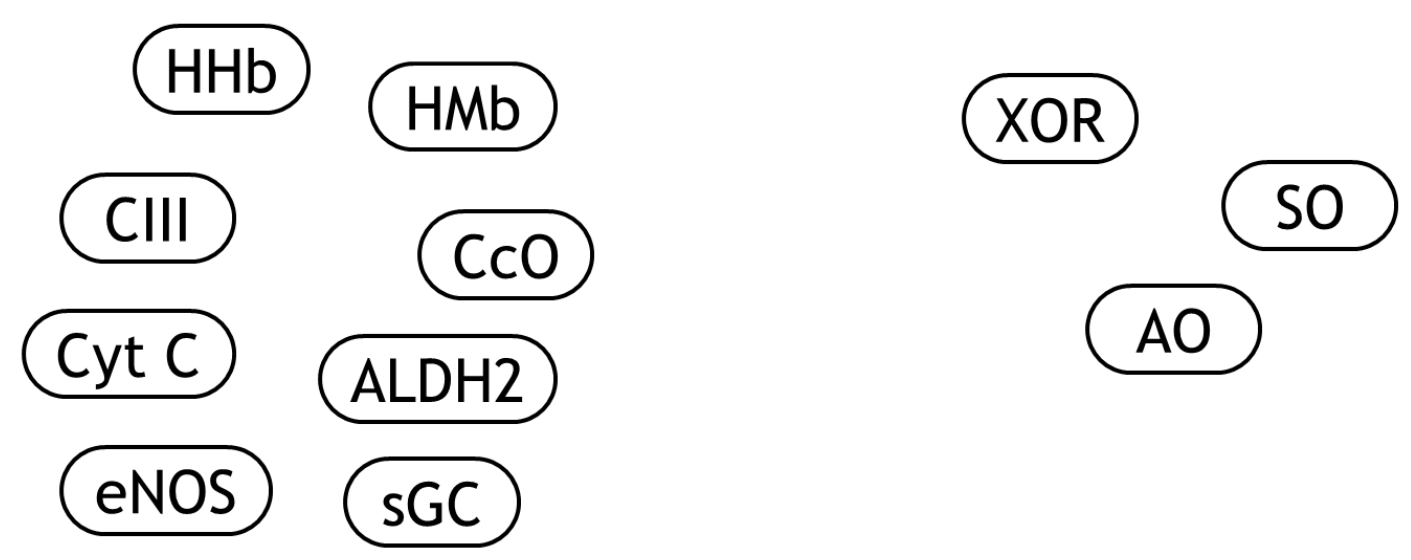




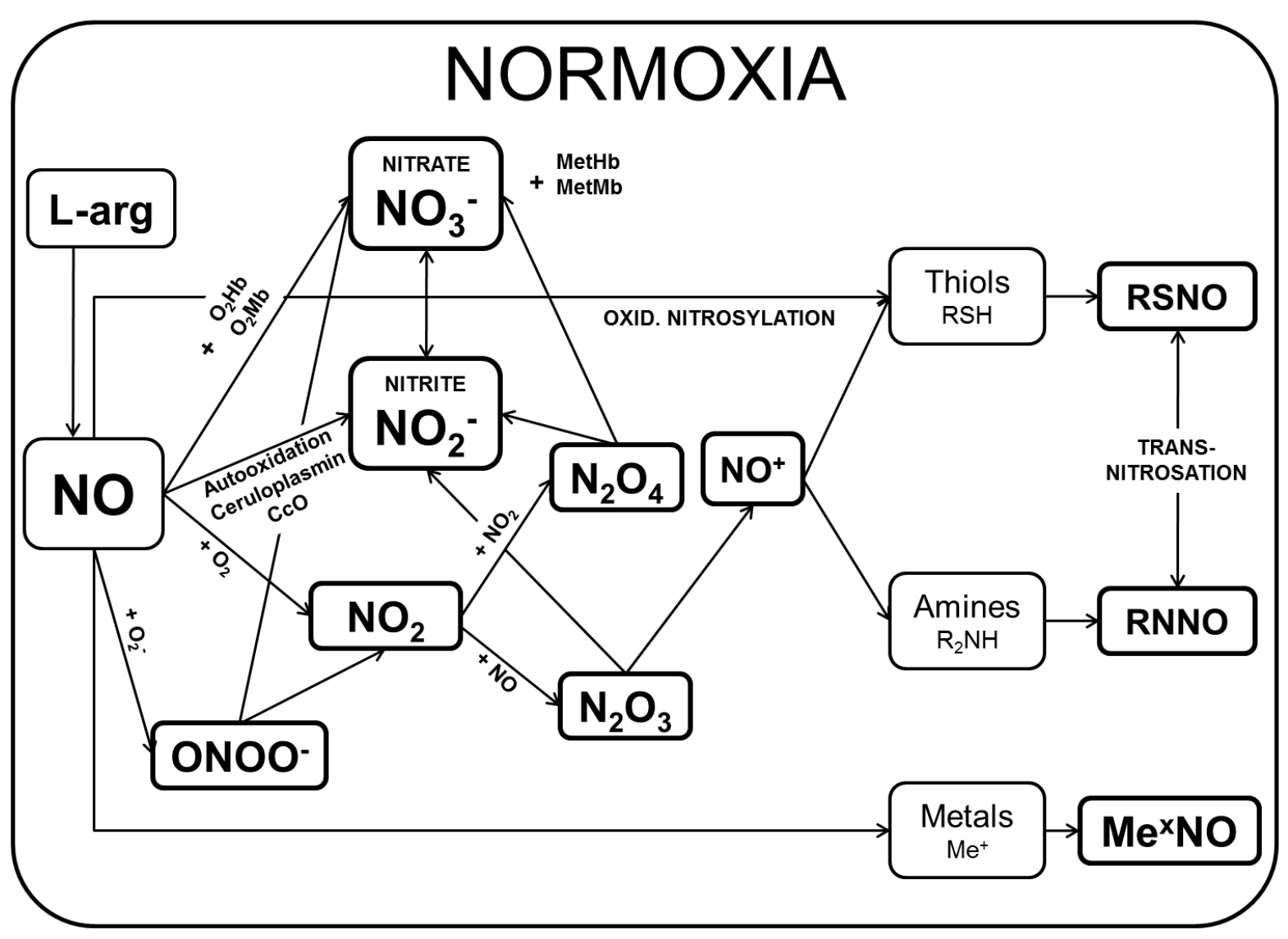



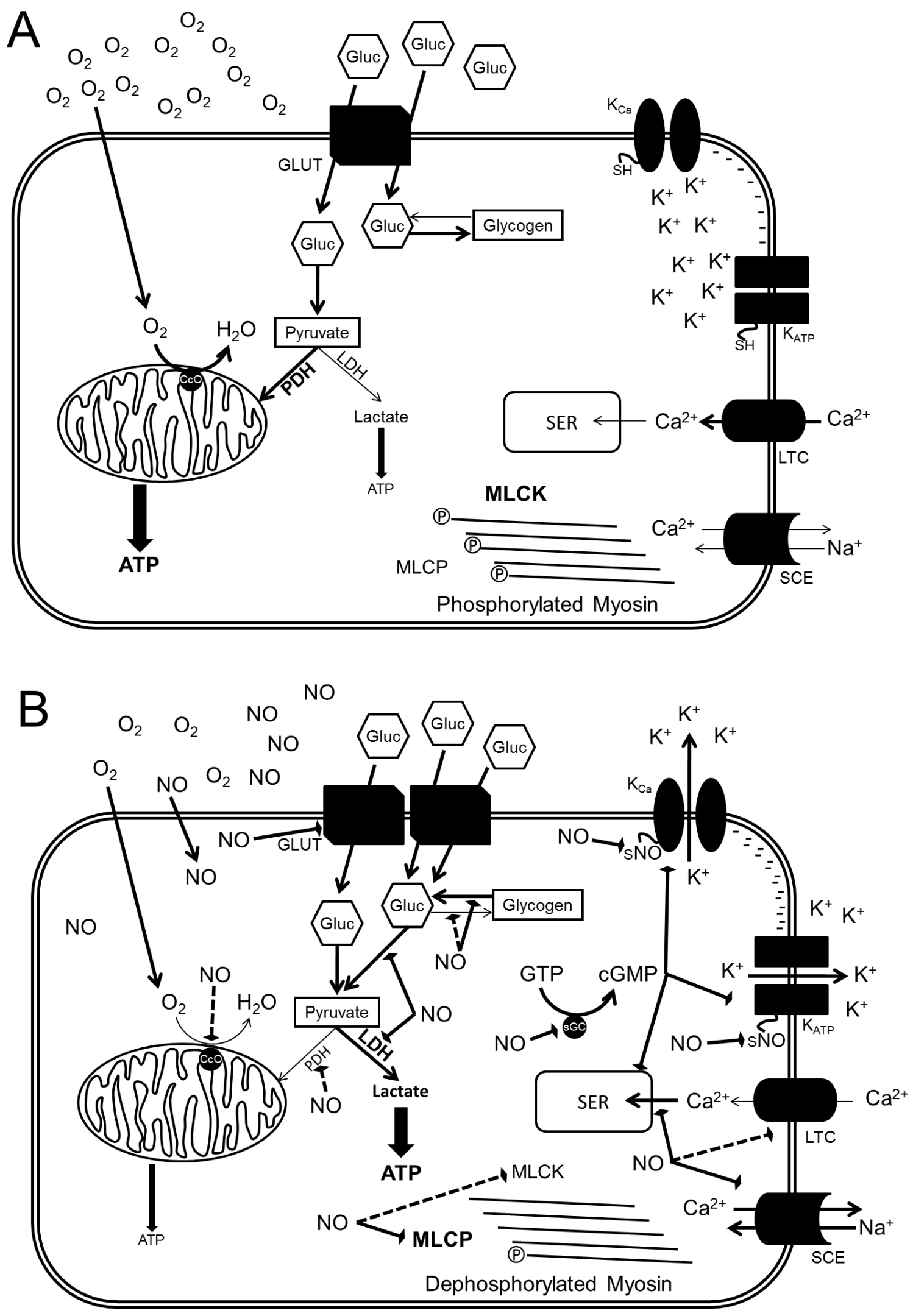


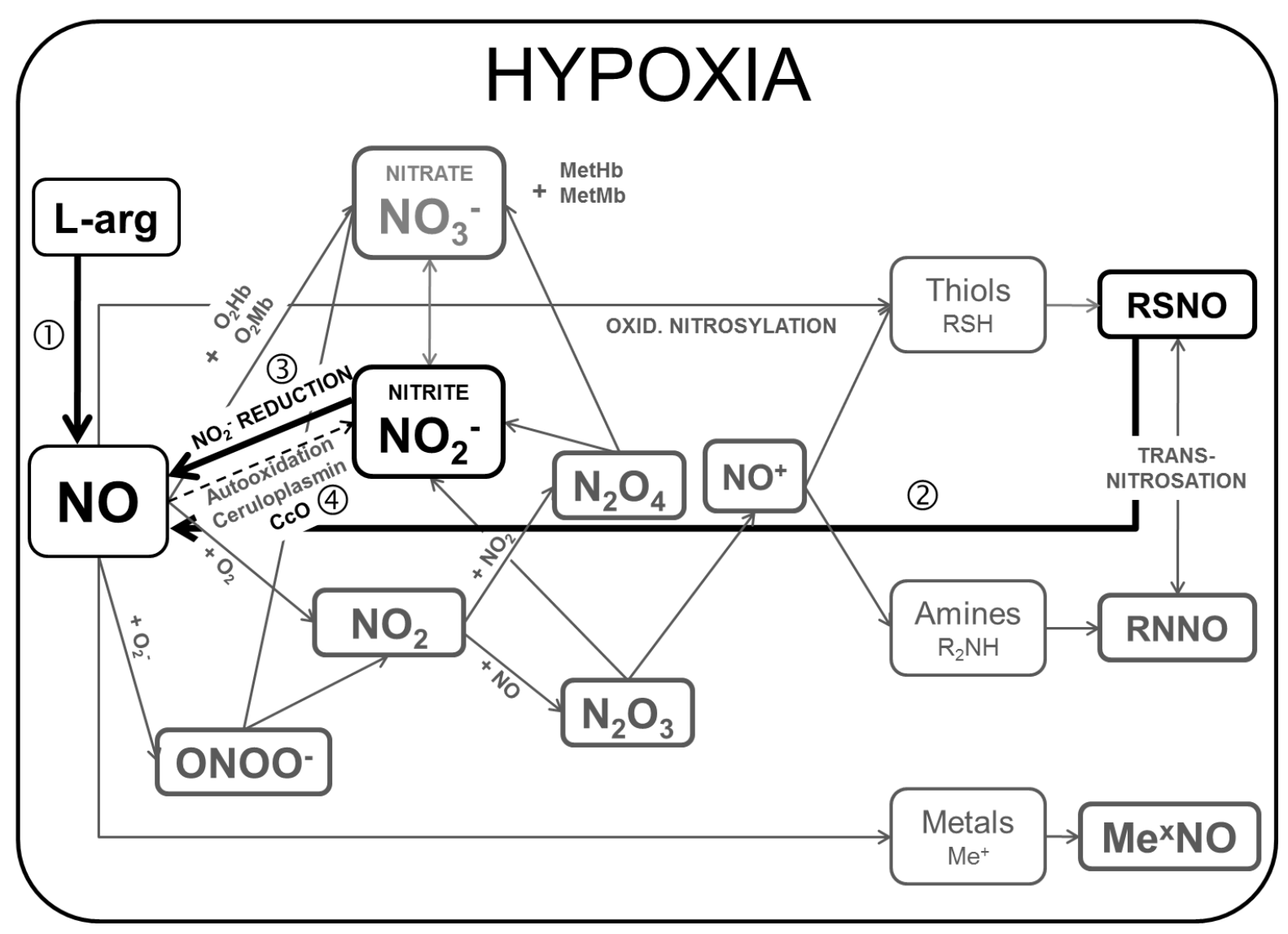

